\title{
Archaeological Investigations at Fort Griffin State Historic Park Shackelford County, Texas
}

Anne A. Fox

Follow this and additional works at: https://scholarworks.sfasu.edu/ita

Part of the American Material Culture Commons, Archaeological Anthropology Commons, Environmental Studies Commons, Other American Studies Commons, Other Arts and Humanities Commons, Other History of Art, Architecture, and Archaeology Commons, and the United States History Commons

Tell us how this article helped you.

This Article is brought to you for free and open access by the Center for Regional Heritage Research at SFA ScholarWorks. It has been accepted for inclusion in Index of Texas Archaeology: Open Access Gray Literature from the Lone Star State by an authorized editor of SFA ScholarWorks. For more information, please contact cdsscholarworks@sfasu.edu. 


\section{Archaeological Investigations at Fort Griffin State Historic Park Shackelford County, Texas}

\section{Creative Commons License}

\section{(c) (1) (8)}

This work is licensed under a Creative Commons Attribution-NonCommercial 4.0 International License 
ARCHAEOLOGICAL INVESTIGATIONS AT FORT GRIFFIN STATE HISTORIC PARK SHACKELFORD COUNTY, TEXAS

Anne A. Fox

Center for Archaeological Research

The University of Texas at San Antonio

Archaeological Survey Report, No. 23

1976 


\section{TABLE OF CONTENTS}

Table of Contents

Page

List of Figures

ii

Acknowledgements

i i

Introduction

1

History of Fort Griffin

4

Archaeological Investigations

Area A

Area B

Area $\mathrm{C}$

Area D

Area $\mathrm{E}$

Cemetery

The Artifacts

Conclusions and Recommendations

Appendix (Cemeteries in the Fort Griffin Area) 


\section{LIST OF FIGURES}

Figure

Page

1. Fort Griffin, ca. 1870-1879 2

2. Map of Fort Griffin, done by Roland Beard, ca. 1940, 6 with indication of 1976 field work.

3. Photographs of Test Trenches 9

4. Map of Investigations in Area A 11

5. Photographs of Excavations in Area A 14

6. Plans and Profiles of Investigations in Area A 16

7. Howarth Map 20

8. Gravestones 23

9. Graves in Civilian Cemetery 25

10. Map of Civilian Cemetery 27

11. Artifacts from Burial $50 \quad 30$

12. Metal Artifacts 37

13. Domestic Articles 39

14. Artifacts from B1acksmith Shop F2 41

15. Glass Bottles 43 


\section{ACKNOWLEDGEMENTS}

The author wishes to acknowledge the help of a number of people who facilitated the field work and preparation of this report. Special thanks go to David Ing of the Texas Parks and Wildlife Department for his patience in answering many procedural questions and his enthusiastic support throughout the project. At Fort Griffin State Park, Park Superintendent Lester W. Galbreath, Park Ranger Roland A. Basham, and Park Attendants Syble Dixon and Luther Harris were particularly cooperative and helpful.

At the top of the Tist of helpful local citizens are Shirley and Clifton Caldwe11, who not only came out and worked in the field, but graciously encouraged the crew's use of their extensive 1ibrary on early Shackelford County and their microfilm of the Fort Gribfin Echo. Mrs. Joan Farmer generously shared her knowledge of local cemeteries. Mr. and Mrs. Cliff Tienert provided assistance in numerous ways. Mr. and Mrs. T. P. Fincher kindly allowed the crew to examine the cemetery on their property.

However, the credit for the accomplishment of this project rests primarily with the archaeological crew who cheerfully labored under trying conditions of high wind, broiling sun, and rain, and came away still enthusiastic about Fort Griffin and its history. Plaudits are due James Ivey, Nancy O'Malley, David Swinehart, and Shirley Van der Veer. The efforts of volunteers Tom Caldwe11, Martha and Bransford Eubank, Robert Fox, and W. R. Van der Veer are also much appreciated. 


\section{INTRODUCTION}

During March, Apri1, and June of 1976 archaeological crews from the Center for Archaeological Research of The University of Texas at San Antonio worked a total of 96 man-days at Fort Griffin, Shackelford County, Texas. The work was done under terms of Interagency Cooperation Contract 0936 with the Texas Parks and Wildlife Department and Antiquities Permit No. 107. The project was administered by Dr. Thomas R. Hester, with Anne A. Fox serving as field director.

The following services were to be accomplished, 1isted in order of priority (for area locations see Fig. 2):

1) AREA A (EnTisted Men's Huts and Mess HaTls GT-G4)

1. Place permanent metal pins and ta 11 wooden stakes at a11 pathway corners.

2. Place permanent metal pins at the known corners of all buildings other than the smal1 EM huts and Barracks K1.

2) AREA B (Officers' Quarters L1, L2 and K2)

1. Stake and mark with metal pins a11 pathways as described above.

2. Place permanent metal pins at a 17 known building corners including those of Barracks $\mathrm{K} 2$.

3) AREA C (Officers' Quarters L8-L12)

1. Locate, stake, and mark with metal pins al1 recognizable gravel and stone pathways within this complex of Officers' Quarters as delineated on plan map.

4) CIVILIAN CEMETERY

1. After grass and weed mowing by park personnel, locate and stake with permanent metal pins as many grave plots as possible.

2. Corstruct a plan map of the cemetery showing the graves and significant topographic features.

5) AREA D (West end of Parade Ground)

1. Archaeologically investigate and map the structure or structures within this area and permanent7y mark a11 corners with metal pins.

2. Backfill exposed features with sand to await permanent stabilization.

6) AREA E (Officers' Quarters L3-L6)

1. Place permanent metal pins and tal1 wooden stakes at all pathway corners.

2. Stake all known building corners with permanent metal pins.

Since the report on the rather extensive investigations directed by the author in 1973 had a 1 imited distribution, much of the introductory material from that report is reproduced and updated in the following pages as background information for the reader. The format of the original report is also followed, to a 1 imited degree, in order to facilitate reference from one report to the other where possible. 
Figure 1. Fort Griffin, ca. 1870-1879 (from Graham 1968:18)

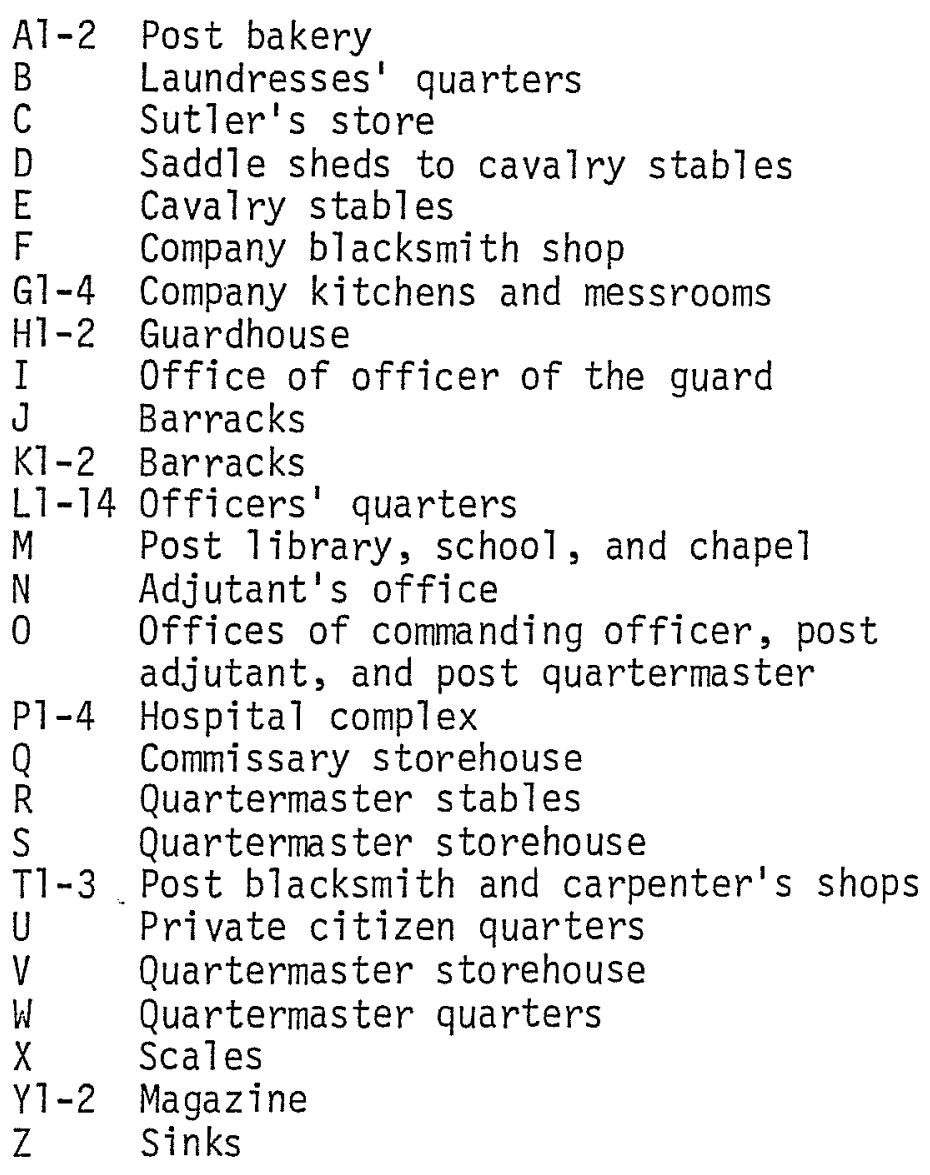




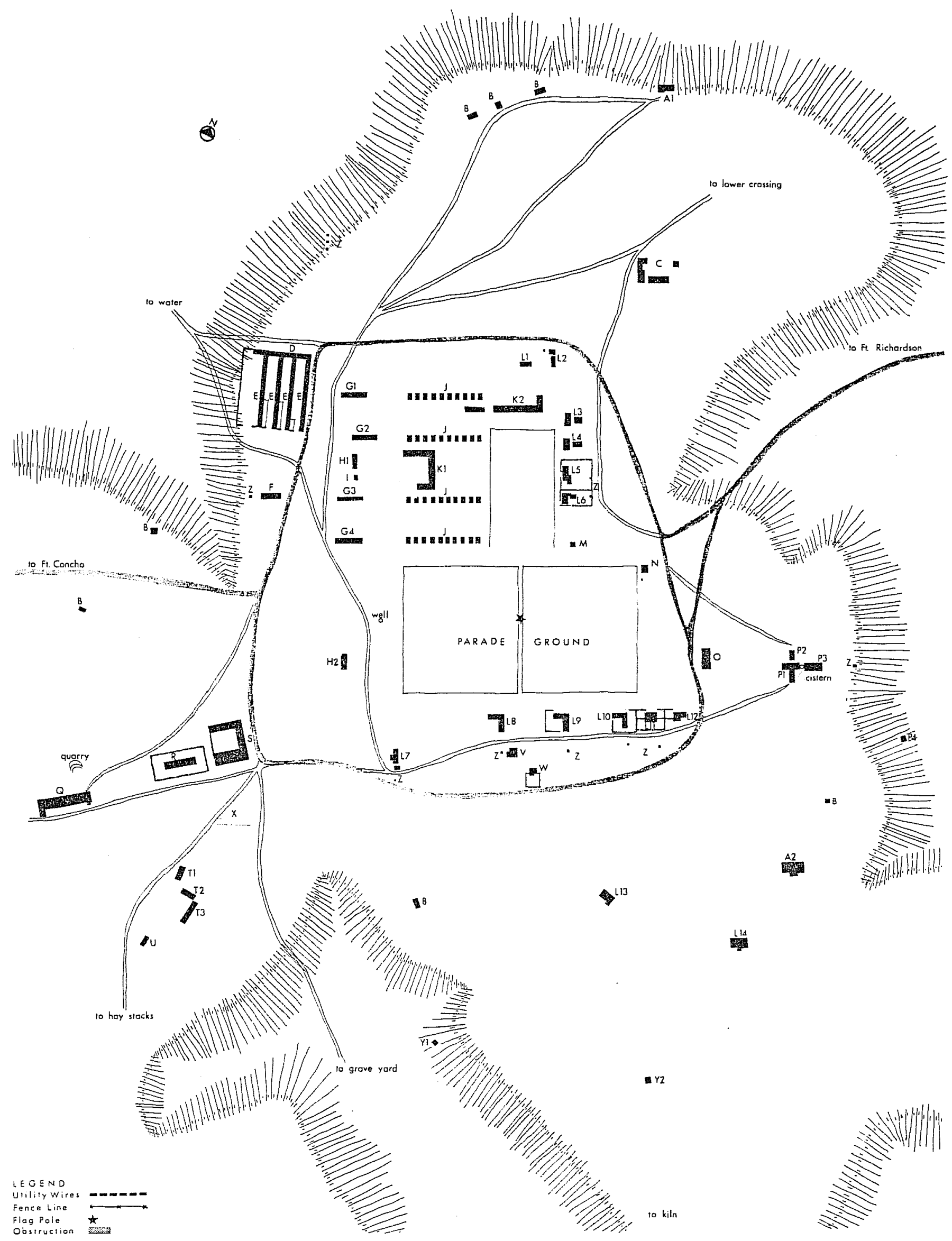




\section{HISTORY OF FORT GRIFFIN}

This report is intended as an account of the 1976 investigations, and should not properly include a detailed history of the fort. For such a complete history the reader should consult Carl Rister's Fort Griffin on the Texas Frontier (1956), or Roy E. Graham's Texas Historic Forts, Part IV, Griffin (1968). Highlights of local history of the town of Fort Griffin and the general area are described especially well in Shackelford County Sketches by Dan $H$. Biggers as edited and annotated by Joan Farmer (1974), Interwoven by Sall ie Reynolds Matthews (1958), and Edgar Rye's The Quirt and the Spur (1967). The following brief historical account (from Fox 1973:2-3) should suffice for background for the recent investigation.

Established first as Camp Wilson in July of 1867, Fort Griffin was given its present name in February of the following year after it was moved from the flats near the Brazos River onto a nearby plateau. The first buildings were of picket construction--vertical logs hastily erected in trenches and roofed with sod or canvas. A 109 cabin was also moved from a neighboring ranch to serve as the commandant's residence (Graham 1968:13). These structures were bui1t around an open area on the northwest side of the present fort, probably the first parade ground. Four rows of ten barracks huts each lined the west side while officers' quarters ranged along the east side. Somewhere in the center of this area was erected the first flagpole (Rister 1956:65), probably opposite the log residence of the commandant.

Upon the arrival of a steam sawmill from the depot at San Antonio, more substantial structures gradually replaced the picket buildings. These appear, from the sketches done by men who were stationed at Fort Griffin (Graham 1968:100, 101, 103) to have been made with rough-hewn boards nailed vertically with butt joints, lathed and plastered on the inside, and the cracks chinked with mortar to keep out the weather. The roof was generally shingled.

The intention was that permanent fort buildings would be constructed of stone. A few substantial stone buildings were built, but the majority of the fort was built of rough-hewn lumber and was never replaced. By the time the fort was abandoned in 1881, many of the original buildings had been dismantled or left to decay. The primary focus of activity was on the larger parade ground to the south, 1aid out in 1869, when another row of officers' quarters was built along the south side.

After its abandonment, Fort Griffin gradually fell into ruin. A few structures were used as residences for a time, others were carried off for use elsewhere. An eyewitness writing for the Dallas News in 1905 (Biggers 1974:131) gave the following description:

Not many of the old landmarks, either in the town or where the old post stood, now remain, and these few are far advanced in decomposition. The barracks, the hospital and the commissary are completely obliterated, as are most of the other Government buildings. A few of the houses occupied by the officers are yet standing, but neglect has pathetically placed its imprint upon 
them. The doors are gone, the windows are broken, the walls careen, the roofs sag, and all must soon collapse. A part of the Sutler's store, which was made of stone, still stands; the Adjutant's office, another stone structure, is now occupied as a residence, and the old rock magazine now serves the purpose of a barn. The parade ground is covered with a heavy growth of grass and mesquite trees shutting out all view of the surrounding country.

Previous Wark

Fort Griffin has been researched, written about, analyzed, and investigated by local historians, journalists, architects, and archaeologists, almost from the moment it was abandoned. A Civilian Conservation Corps crew of five laborers under the supervision of Roland Beard spent over a year investigating the hill top in the early 1940's. Unfortunately, extensive chaining of mesquite trees and brush was carried out in the $1960^{\prime} \mathrm{s}$ which eliminated or scattered a great deal of the remaining architectural evidence such as chimney bases and stone piers present at the time of the 1940 excavations. This disturbance was confirmed by archaeological excavations of specific buildings carried out by the Texas Archeological Research Laboratory in 1969 (see 01 ds 1969) and by the Texas Archeological Salvage Project in 1971. For this reason it was deemed advisable to do a general assessment of the remainder of the fort to determine which structures might most profitably be further excavated and which are too nearly obliterated to be worth the expenditure of time and money to investigate in this fashion. This assessment was accomplished in 1973 by a crew under the direction of Anne A. Fox, and published by the Texas Archeological Survey under the title, Archeological Investigation at Fort Griffin State Historic Park, Texas, February, 1973.

ARCHAEOLOGICAL INVESTIGATIONS

Procedures and Methods

The map used as a reference for location and identification of structures at the fort is a composite map from Graham's study, reproduced here as Figure 1. Also used extensively was a map drawn by Roland Beard as a result of his work in the $1940^{\prime} \mathrm{s}$, which is partially reproduced here as Figure 2. All mapping was done with the aid of a plane table and alidade, with measurements in feet and inches in order to correspond with the work of previous seasons.

In many cases, it was possible to go directly to wooden stakes erected in 1973 to find pathways, chimneys, and corners of structures. Extensive use was made of data recovered in the 1973 investigations in relocating structures. Experience gained in 1973 in reading soil changes was especially helpful for locating walls of picket construction, which show up plainly to the practiced eye. 
Figure 2. Map of Fort Griffin, done by Roland Beard, ca. 1940, with indication of 1976 field work. Areas of investigation - A, B, C, etc. Test Trenches - A76, B76, etc. Metal pins indicated by circles. 

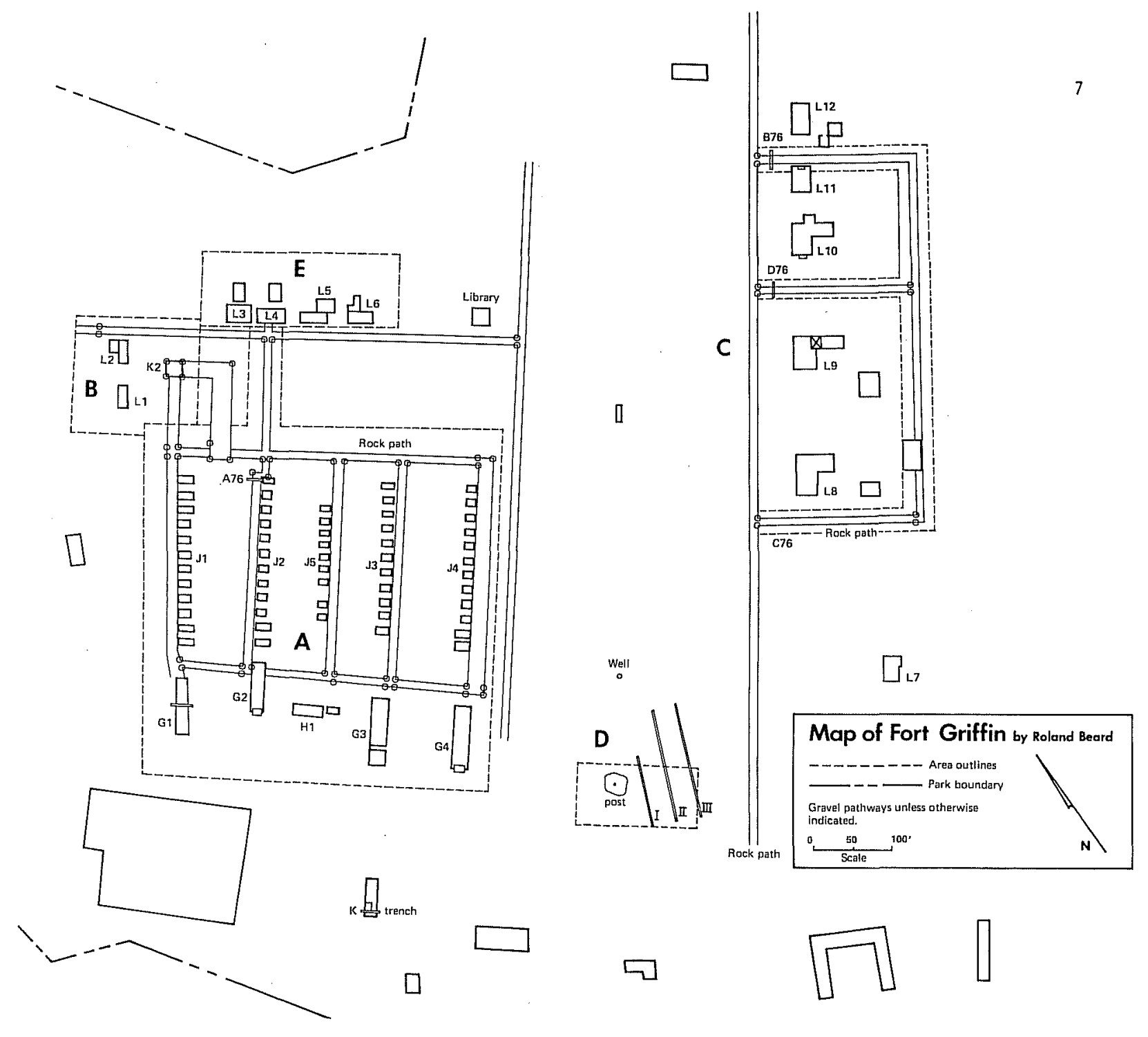
Standard archaeological procedures for excavation and recording were followed throughout the work. A11 metal stakes were stamped with the designation of the unit to which they pertained, and recorded on the field map (Fig. 2). Artifacts recovered were processed and cataloged, and will be turned over to the Texas Parks and Wildlife Department on publication of this report.

\section{AREA A}

\section{Pathways to Enlisted Men's Huts}

The outlines of the original pathways along the rows of Enlisted Men's huts were relocated. Metal pins 3/4-inch in diameter and three-foot wooden stakes were placed at al1 pathway corners; the pins were stamped with letters and numbers to correspond to the indications on the map (Fig. 1). A test trench (A76) was excavated across pathway $\mathrm{J} 2$ in order to examine the method of construction (Figs. 3 and 6). The pathway appears to have been constructed by removing the topsoil to the top of the red clay, in this case approximately 6 inches below, then filling the resulting trench with local gravel, mounded slightly at the center and draining to either side. On paths $\mathrm{Jl}$ and $\mathrm{J} 2$ flat stones were set on edge as a boundary, also effectively containing the gravel. Artifacts such as nails, buttons, and other small objects were noted in the top 3 inches, but none were found below that point. In an attempt to determine the source for the gravel used on the fort, a sample of gravel from A76 was compared with one taken from an old gravel quarry on the edge of the escarpment, north of the present-day flagpole and lookout point. From this comparison, it appears that the pathway gravel could have come from this quarry, and that this quarry could be used as a source for gravel for restoration of the paths.

A search was conducted in 7 ine with $\mathrm{J} 2$ across the first parade ground to determine the location of the one Beard mapped (Fig. 2). The onty evidence found was a group of flat stones part way across which were more or less in line with the projected path. In hopes of finding some trace of the original flagpole (Rister 1956:65) this area was carefully examined, but nothing was present except the flagstones. The path was arbitrarily marked with metal pins as it was indicated by Beard.

When mapping was under way, it became apparent that Beard was in error when locating the pathways running northwest to southeast at either end of the barracks rows, and pathway $\mathrm{Jl}$ along the northern row of huts. As located and mapped this time (Fig. 4), the pathways run perpendicular to each other rather than at the angles shown by Beard (Fig. 2).

\section{Kitchen-Mess Buildings}

Construction: rough frame, stone floors, shingled roofs, large stone fireplaces (Graham 1968:100). 
Figure 3. Photographs of Test Trenches. (right) Test Trench A76 - Looking west across trench, photograph shows west profile with stone slab and edging.

(1eft) Test Trench across GT - Looking south, showing rubble "pavement" in north end. 

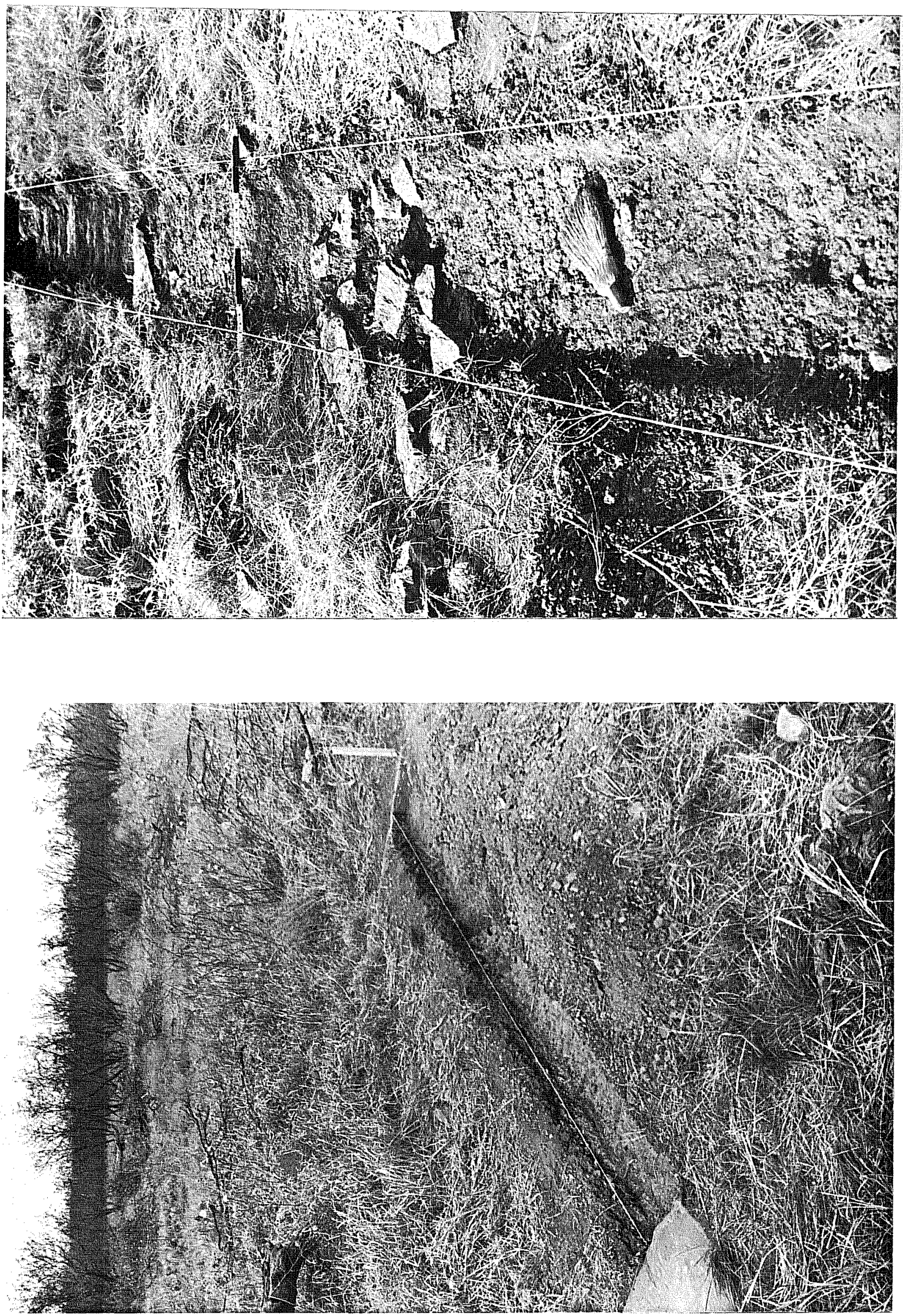
Figure 4. Map of investigations in Area A. Locations of marked metal pins and projected wa11 lines of Kitchen-lless Buildings are indicated, as well as corrected pathway locations (see page 8 ). 

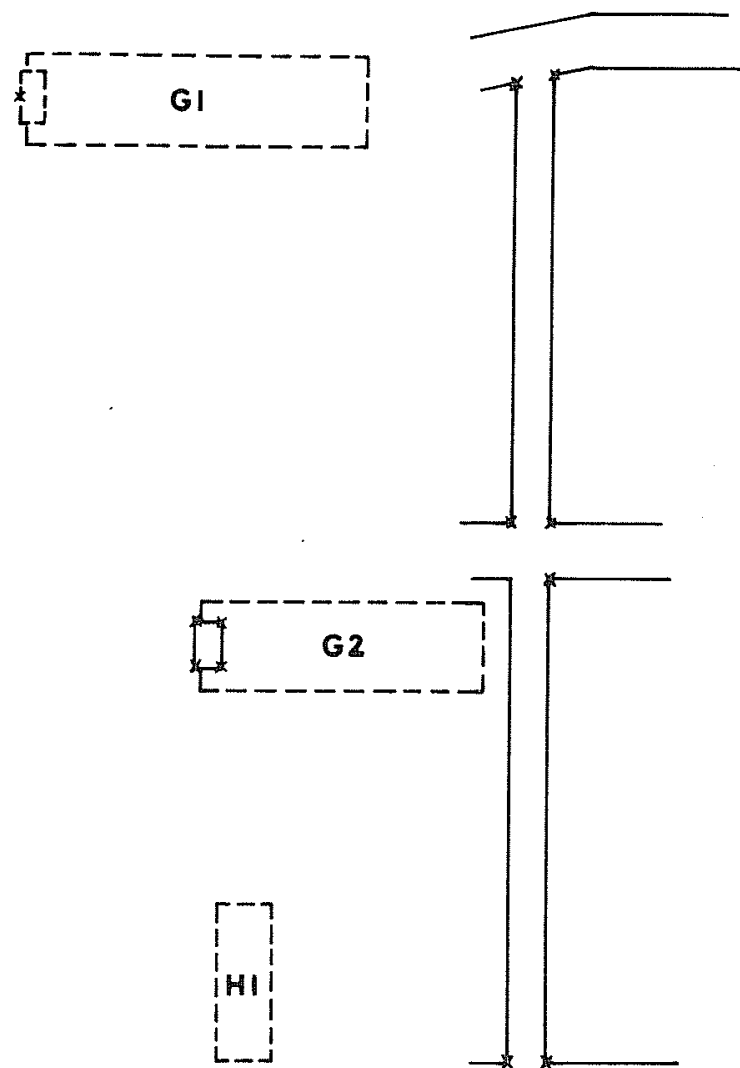

Station
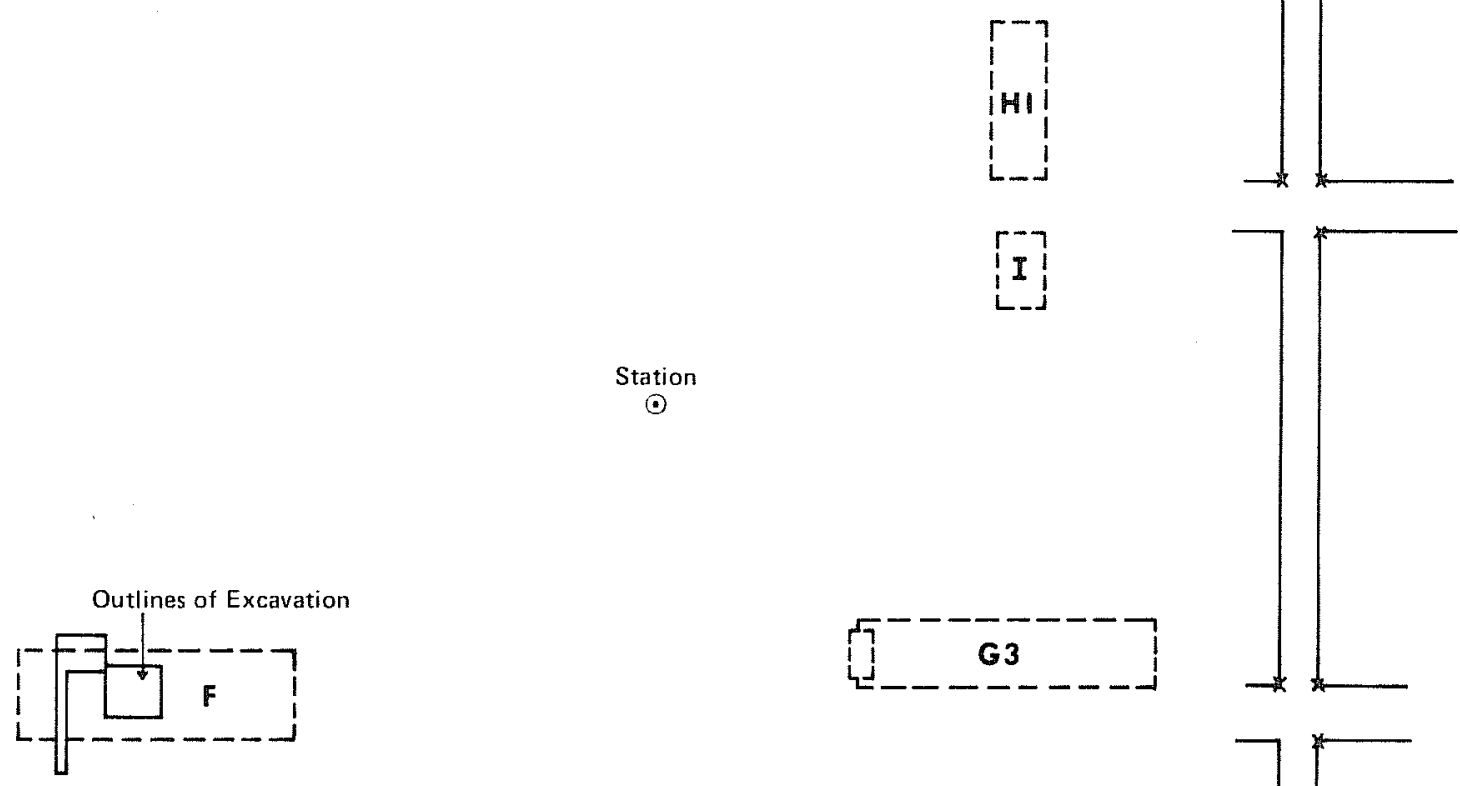

\section{Map of West End of Barracks Area}
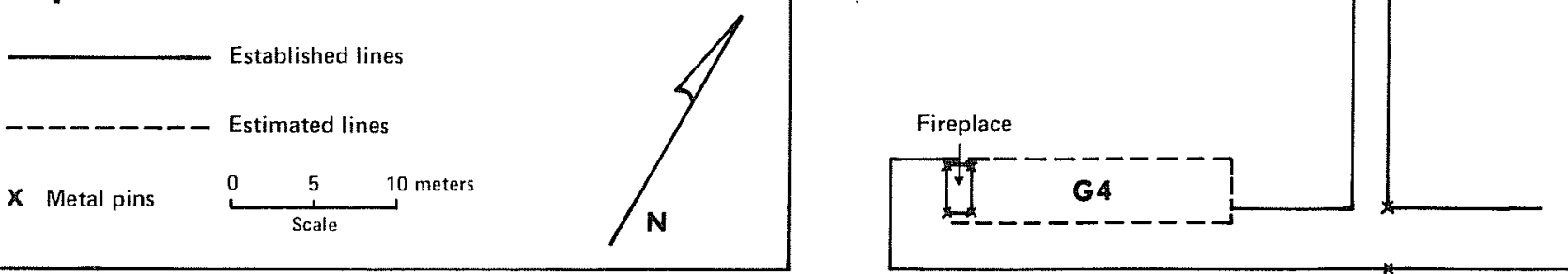
Dimensions: $15^{\prime} \times 63^{\prime}, 16^{\prime} \times 60^{\prime}, 13^{\prime} \times 60^{\prime}, 13^{\prime} \times 60^{\prime}$ (National Archives 1869).

History: built about 1868; by 1879 one, $15^{\prime} \times 63^{\prime}$, was gone; and one, $13^{\prime} \times 60^{\prime}$, was reduced to a shed, "falling-down rotten" (National Archives 1879).

Since building corners were not definitely established during the 1973 investigations of the kitchen-mess buildings, metal pins were placed at the corners of kitchen chimneys, where these could be located. The chimney for $\mathrm{GT}$ was identified by observing the burned stone and firereddened earth directly under the hearth area (Fig. 6). All other stones of which the structure was built have been removed (see Fox 1973:23).

A test trench $7^{\prime} \times 22^{\prime}$ was excavated across the center of $\mathrm{Gl}$ in an attempt to locate the wall 7 ines of the building. Just below the surface was what appeared to be a "pavement" of sma11, irregu7arly spaced angular stones, which seemed too rough to have been a floor. These ended abrupt7y at a point three feet from the north end of the trench. As this stoney layer was not present in the southern half of the trench, no definite edge for the building could be postulated on this side. The sudden cessation of stones on the north side can be laid to a number of causes. If it is the natural condition of the ground in this area to be covered with such a stoney "pavement", as appears to be true judging from other work nearby (Fox 1973:22, and excavations in the B1acksmith Shop area in this report), the edge of this layer may indicate excavations to clay for a pathway, as reported above for trench A76. It seems possible that the locations of kitchen-mess buildings might be accomplished by completely stripping the area and noting the edges of this "pavement". Judging from the number of artifacts found in this smal1 test trench (see below), such a project should yield considerable information about mess hal1 activities and perhaps indicate later uses of the structure.

The chimney at G2, located in 1973 (Fox:22), was relocated and marked with metal pins. Since the chimney at G3 was not located in 1973, no concerted effort was made to locate it at this time. Acting on observations made in 1973, what is left of the chimney base at G4 was careful7y exposed and mapped (Fig. 6), with an eye to possible future restoration of this structure. Metal pins were installed at the four corners of the chimney, and the area was covered with plastic sheeting and back-filled.

Guardhouse $\mathrm{H1}$

Since a concerted effort was made in 1973 to locate the pertinent features of this structure without success, no further work was done. The line of stones across the front of the structure is sufficient to mark its location.

Company Blacksmith Shop $F$

Construction: in 1869 there were 3 , of $10 \mathrm{~g}$ and slab construction by 1875 there was 1 , of picket construction 
Figure 5. Photographs of Excavations in Area A. (upper) Chimney base at Kitchen-Mess Hal1 G4, looking west.

(lower) Excavations in area of Blacksmith Shop F, looking south. 

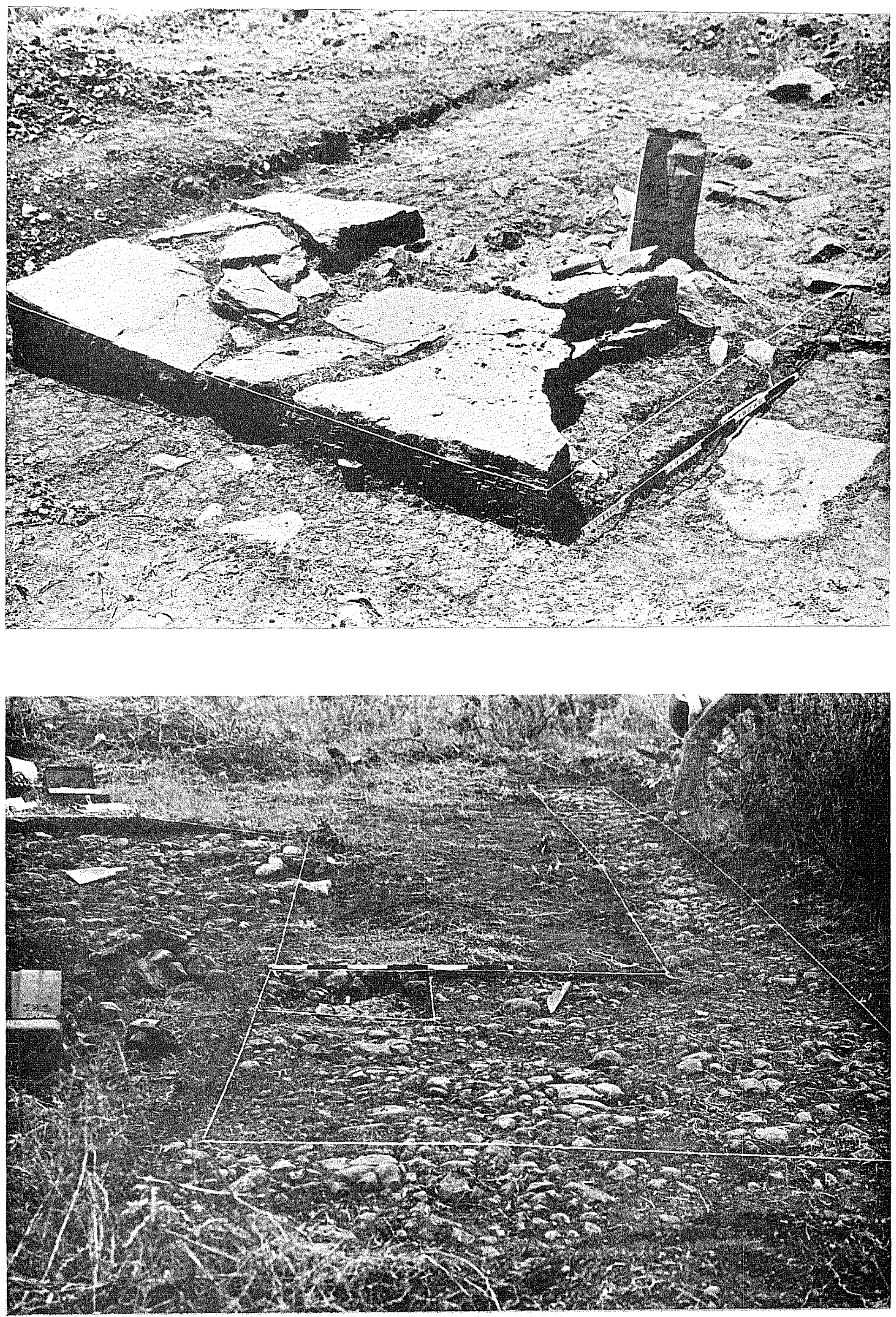
Figure 6. Plans and Profiles of Excavations in Area A. 


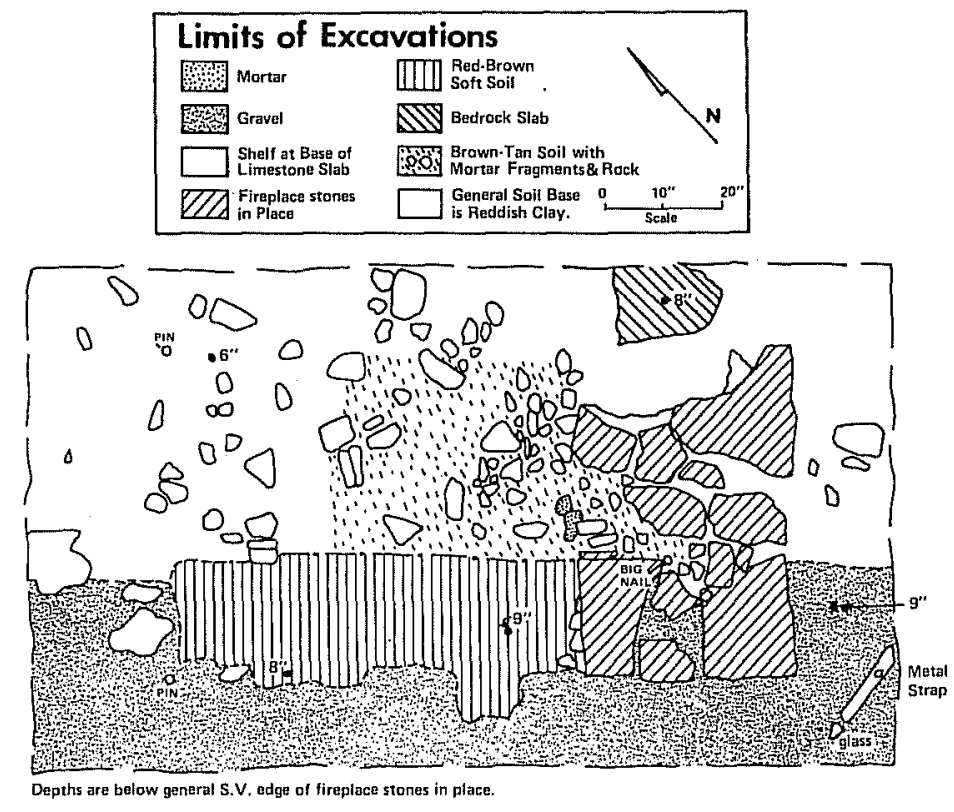

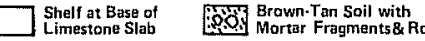

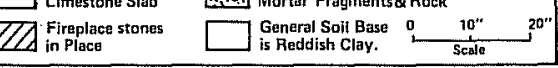

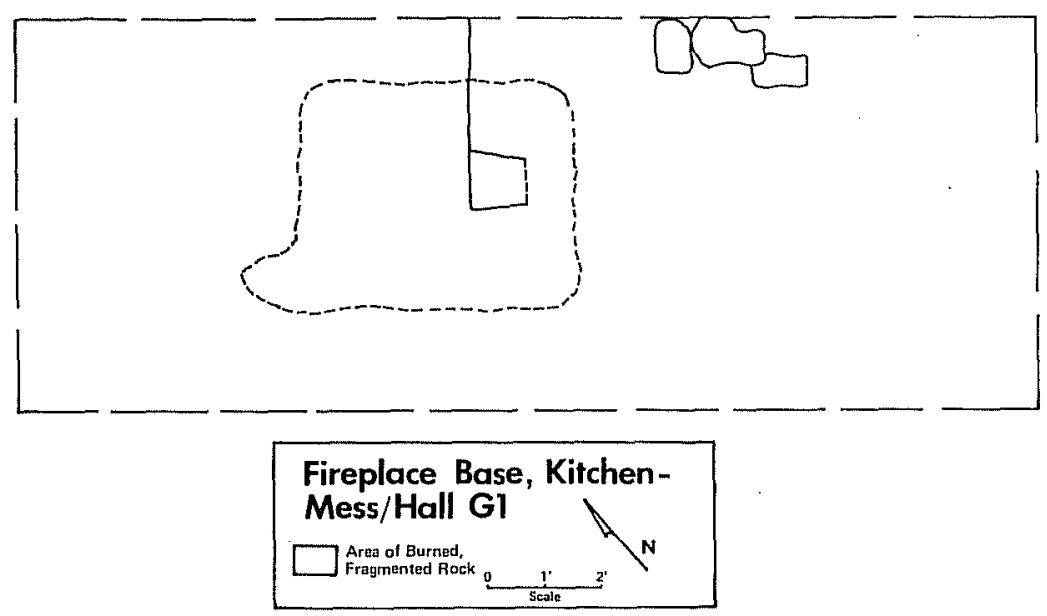

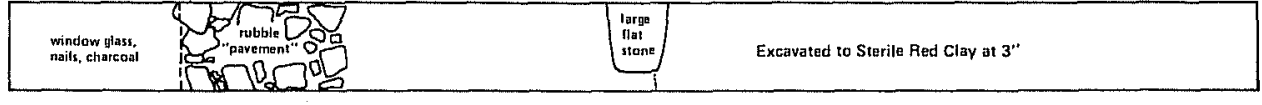

\section{Stone stab in From of
Ennlisted Mern' Hut}

GROUND SURFACE

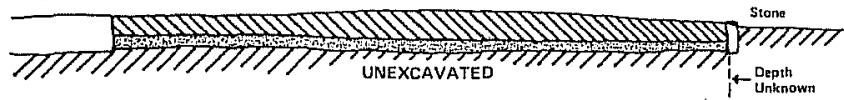

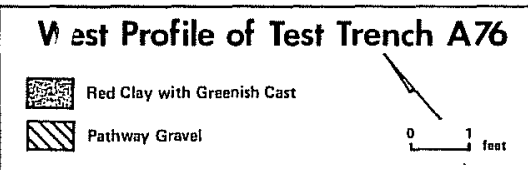

Plan of Test Trench Across G1

ㄴ.r.

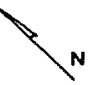


Dimensions: $\begin{array}{ll}1869--16^{\prime} \times 47 & 1 / 2^{\prime} \\ 1875--15^{\prime} \times 40^{\prime}\end{array}$

History: three of these were apparently built directly west of the barracks huts before 1869 (National Archives 1869); by 1875 a more permanent one had taken its place (National Archives 1875).

Using information gained in the 1973 testing, another attempt was made to locate this structure, supposed7y west of G3 (Fox 1973:27). An area $16^{\prime} \times 58^{\prime}$ within which the building should be located was marked out using an alidade and plane table. A trench $2^{\prime} \times 26^{\prime}$ located six feet east of the west end of this area was stripped of grass and weeds. Directly under the topsoil was a thin layer of gravel which overlay a pavement of larger gravel and small stones, inlaid with chunks of iron, square nails, and occasional glass fragments (Fig. 5). The cleared trench was expanded to the east and opened up into a 10-foot square over what appeared to be a concentration of larger rocks. The same combination of large gravel and artifacts appeared to extend over the entire area. A7though great care was taken to examine all of the area cleared, no features were found which would indicate structure of any kind. All artifacts were left in place, then collected in a controlled grid in order to observe their distribution. No significant information was obtained from this exercise, however.

Judging from the artifacts recovered, (1isted in Artifacts section) there is no question that the blacksmith, or at least a farrier, was located somewhere in the immediate vicinity. The fact that no evidence was found of a permanent forge, the base for an anvil or post holes for installation of other equipment, or trenches indicating picket construction probably indicates that the actual location has not yet been found.

AREA B

Officers' Quarters $L .1$ and $L 2$

Construction: rough frame, lathed and plastered inside, shingled roof, open stone fireplaces (see Fox 1973:14-75).

The pathway across the northern edge of the parade ground in line with pathway J1 was marked with metal pins. Corners of Officers' Quarters L1 and L2 were similarly marked.

Barracks $k 2$

Construction: stockade pickets set in trenches, no data on roof, open stone fireplaces.

Dimensions: center wing approximately $20^{\prime} \times 120^{\prime}$, west wing $20^{\prime} \times$ undetermined length, east wing $20^{\prime} \times 68^{\prime}$ (Fox 1973:17).

History: built in 1872 or early 1873, reported uninhabitable in 1875 (National Archives 1875), gone by 1876 (Graham 1968:98); used by Company D, 4th Cavalry (National Archives 1873). 
The known corners of Barracks $K 2$ were marked with metal pins. The precise location of the southeast corner was not located in 1973 because it was in the road bed. Since that road is no longer in use, the area was excavated and this corner was found and permanently marked (see Fig. 1).

AREA C

Pathways Around Officers' Quarters $18-L 11$

Beard's map shows paths running along the sides and across the back of these quarters. Test trenches across three locations (B76, C76, D76, Fig. 2) showed no evidence of these. However, there are scattered indications of a flagstone pathway along the southwest side of L8, and this path was tentatively marked for future reference. One possible source of confusion in regard to pathway locations may have been the service road which once ran across the back of these houses (Fig. 1), the route of which is still visible because of a difference in vegetation over the road bed.

\section{AREA D}

\section{West End of Parade Ground}

Apparently very little is known of the area at the southwest end of the main parade ground. There is no indication in Beard's notes that he worked in this area (Beard n.d.). A map drawn from memory many years later by Jacob Howarth who was stationed at Fort Griffin in 1876 indicates a guardhouse was located there (Fig. 7). However, no other early maps of the fort contain this information. Apparent7y this eyewitness' map was the source for Graham's location of Guardhouse H2 (Fig. 1). An official report of buildings on the post in 1879 (National Archives 1879) describes what was apparent7y a new guardhouse with dimensions of $25^{\prime} \times 45^{\prime}$. This is not surprising, since previous reports had complained about the poor condition and inadequacy of the first guardhouse located between G2 and G3 (National Archives 1875). The new guardhouse was described as being of picket construction, which should leave distinctive traces in the form of trenches containing red clay (see Fox 1973:17-18) and numerous nails and other artifacts scattered nearby.

In order to be certain not to miss whatever structure might have stood in the area, park personnel mowed the entire space southwest of the parade ground, between the berm next to the Visitor Center and the we17. A concentration of rocks which at first looked as if it might be related to a building was found to be part of a fence constructed at a later time. The remainder of the area not included in this investigation was crossed by a series of three test trenches $7^{\prime} \times 100 '$ ', 30 feet apart, laid out in such a way as to intersect any structure with a length of 45 feet (Fig. 2). After the sod was removed, these trenches were trowelled to a depth of 6 inches. Trenches II and III were extended to 150 feet in length. Occasional fragments of glass and a square nai 1 
Figure 7. Howarth Map. Sketch of Fort Griffin drawn from memory by a man who was stationed there in 1876 (Graham 1968:104). Note the location of a Guardhouse and ceremonial guns at the southwest end of the parade ground. 


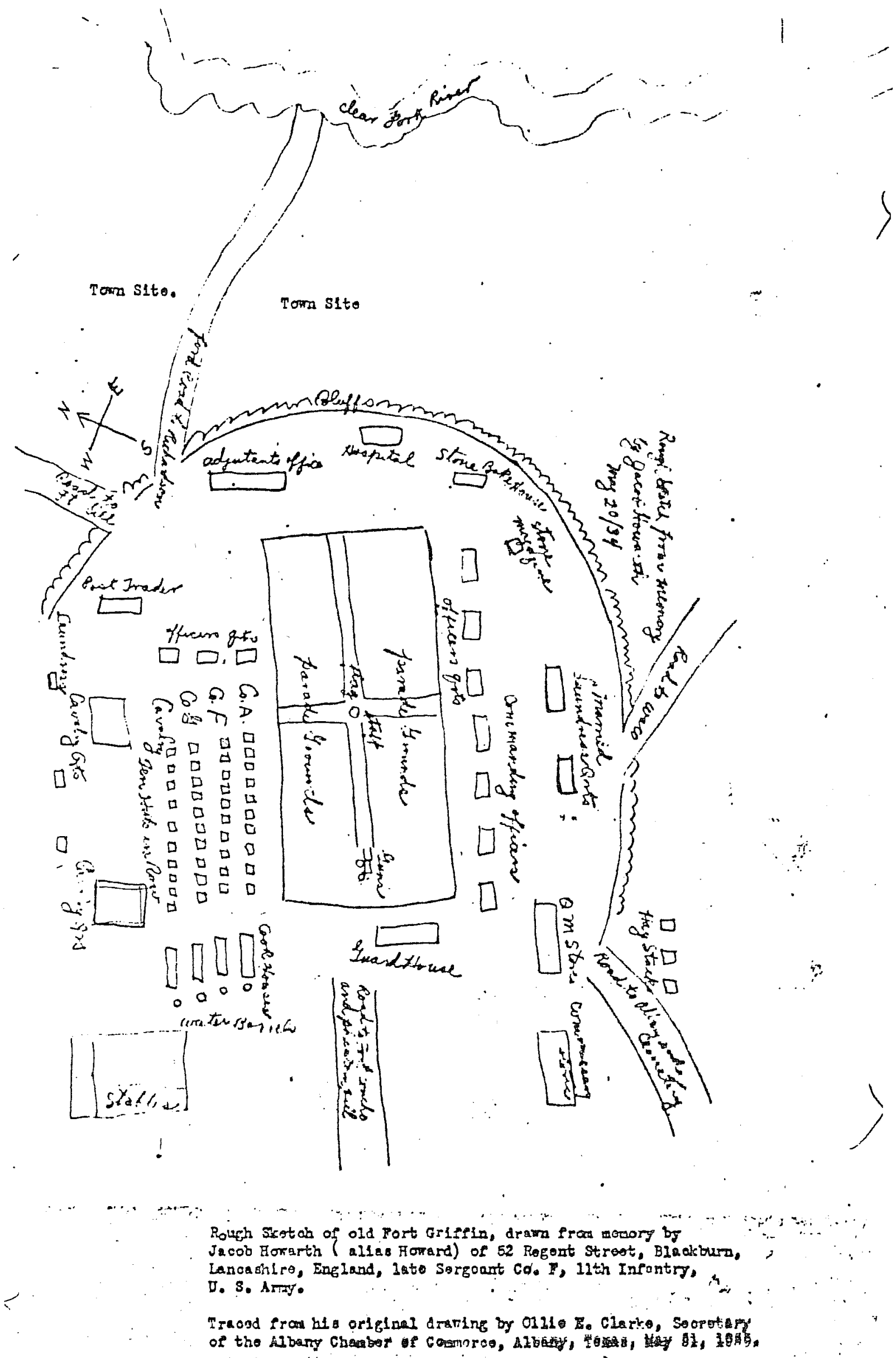


or two were the only indications of human activity found in trenches I and II. In trench III a number of artillery friction primers were found (Fig. 12), tending to confirm Howarth's location of the ceremonial cannon at this end of the parade ground (Fig. 7). It is interesting to note that the 1973 excavations turned up identical brass tubes at Officers' Quarters L2, both around the chimney and in the latrine fil1, perhaps indicating that this was the residence of the officer in charge of such matters at some time.

Whatever the uses of Area D, it appears that there was never a guardhouse or any other sizable structure built in the vicinity.

AREA E

Officers' Quarters $13-16$

The location of the pathway which ran the length of the first parade ground in front of the officers' quarters was staked with metal pins. The corners of L3, L4, and L5 were also marked as located in 1973 (Fox 1973: P1ate 1). Since it was determined in 1973 that $L 6$ has been nearly obliterated (Fox 1973:13), no attempt was made to mark this building.

\section{CEMETERY}

On the east side of Highway 283, with in the boundaries of the park, lies a cemetery recently enclosed by a barbed wire fence by park personnel. It is not far from the military cemetery for the fort, but apparent7y has no connection with it. At first glance, this appears to be a small family plot similar to numerous others in rural areas of the state. However, when the archaeological crew began to clear away the weeds preparatory to mapping the site, it soon was obvious that this was more than a one-family affair.

A total of 50 graves or possible grave sites was marked by the survey crew with numbered pins to correspond with those on a map, drawn with alidade and plane table (Fig. 10). A careful record was made of each grave, which included a freehand sketch. This information will be filed with the field notes in the official records of the excavation.

Most of the graves were marked only by a stone or two set upright in the ground, some by mounds of rock, and some merely by a depression in the ground. A few were surrounded by carefully constructed rock wal1s in a form of crypt (Fig. 9). Of the latter, two had large stone slabs laid across them marked as follows: "I.H.S./VIRGIL J. HERVEY" and "LITTLE LULU HERVEY". These were the only inscribed grave markers found in place. Park personnel pointed out two additional, more elaborate markers which had been found lying on the ground within the cemetery a number of years ago and stored behind a shed for safekeeping (Fig. 8). These contained more information: 
Figure 8. Gravestones. These were removed from the cemetery on Highway 283 and are now stored in the park. 

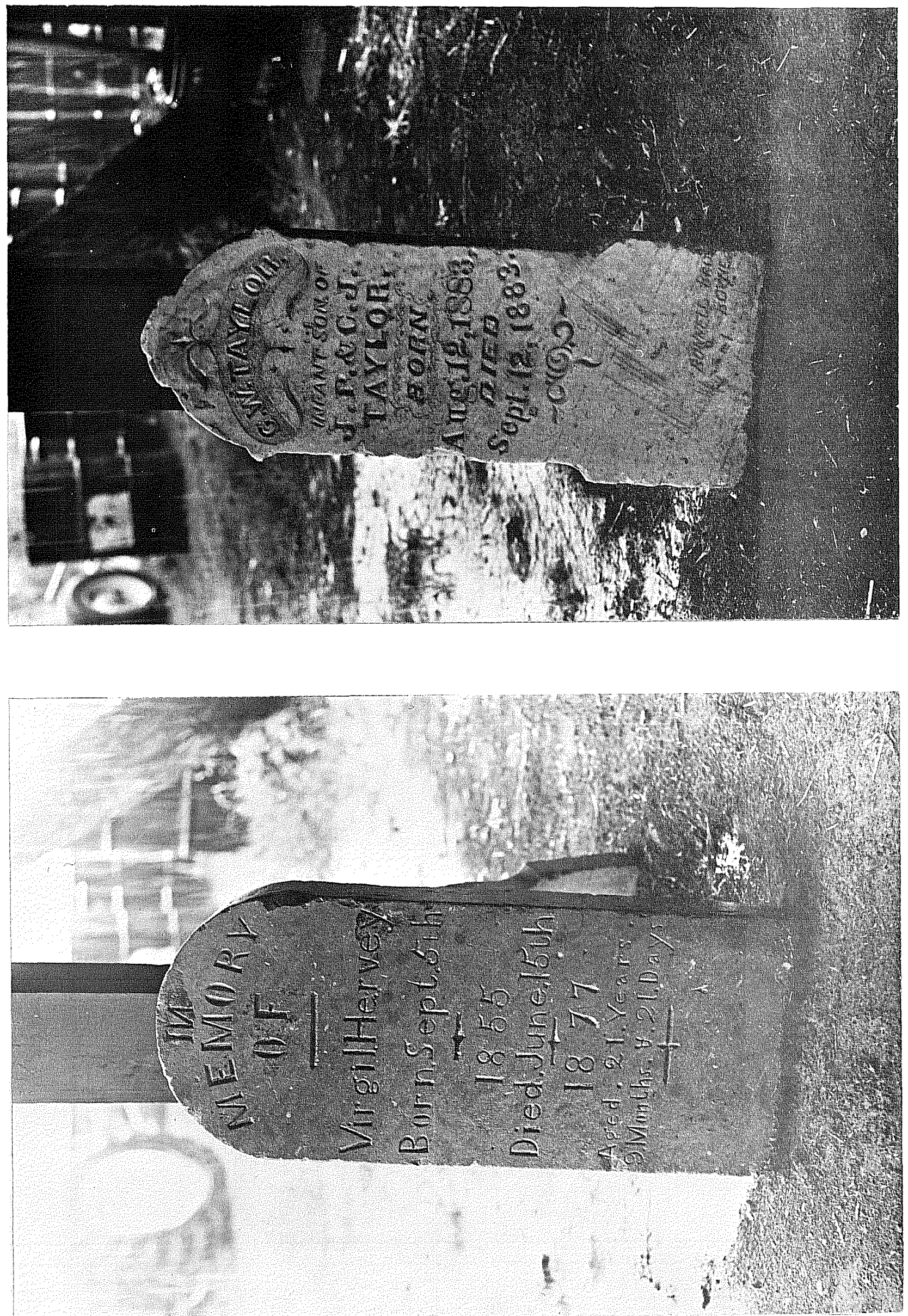
Figure 9. Graves in Civilian Cemetery.

(1eft) Crypts of Little Lulu Hervey (45) and

Virgil J. Hervey (44) taken from the east, with edge of Fort Griffin plateau visible in right rear.

(right) Typical grave with crude head and foot stones. 

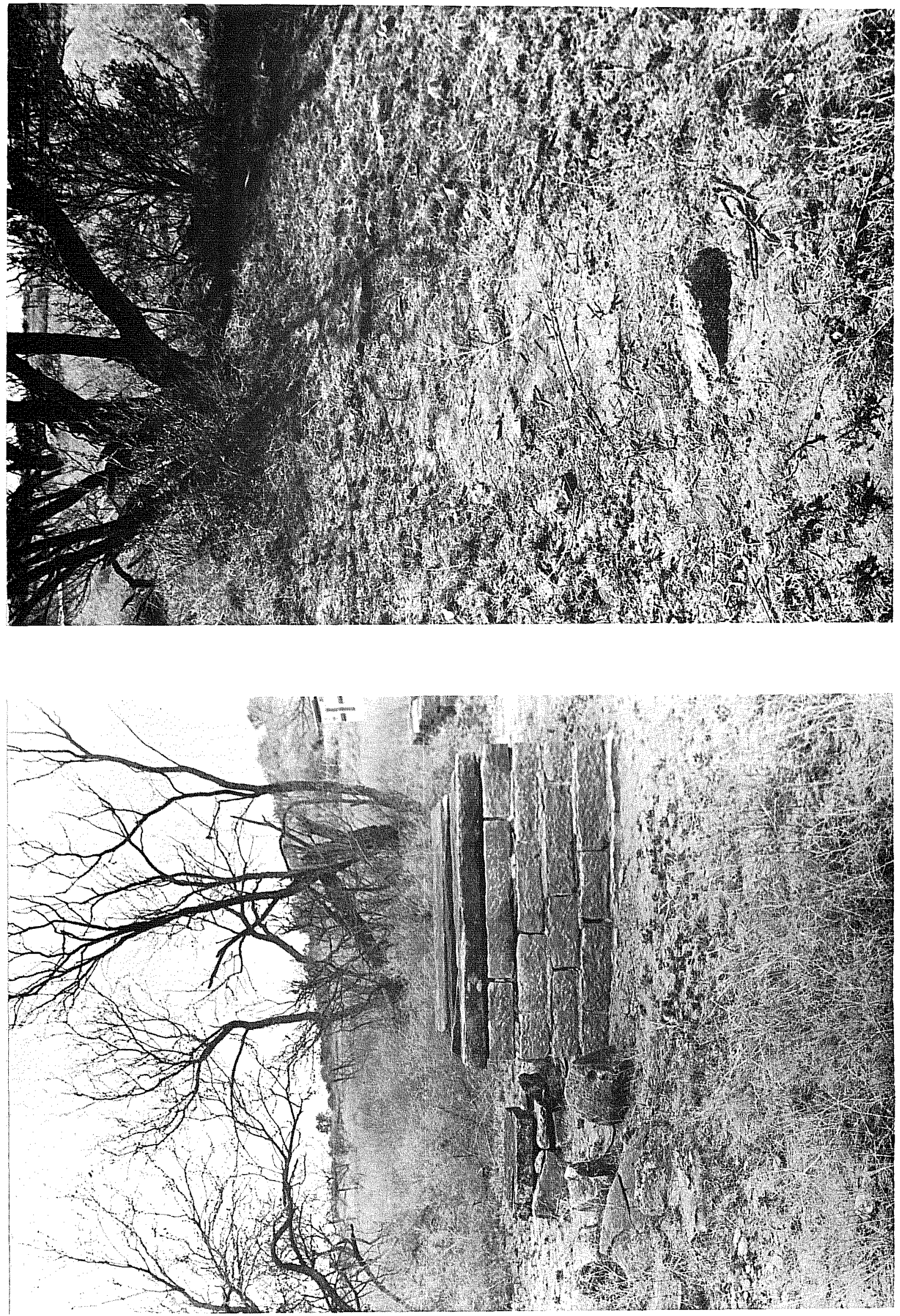
Figure 10. Map of Civilian Cemetery. Map done during 1976 field work. Each grave is worked with a numbered metal pin, as indicated by circles on map. 


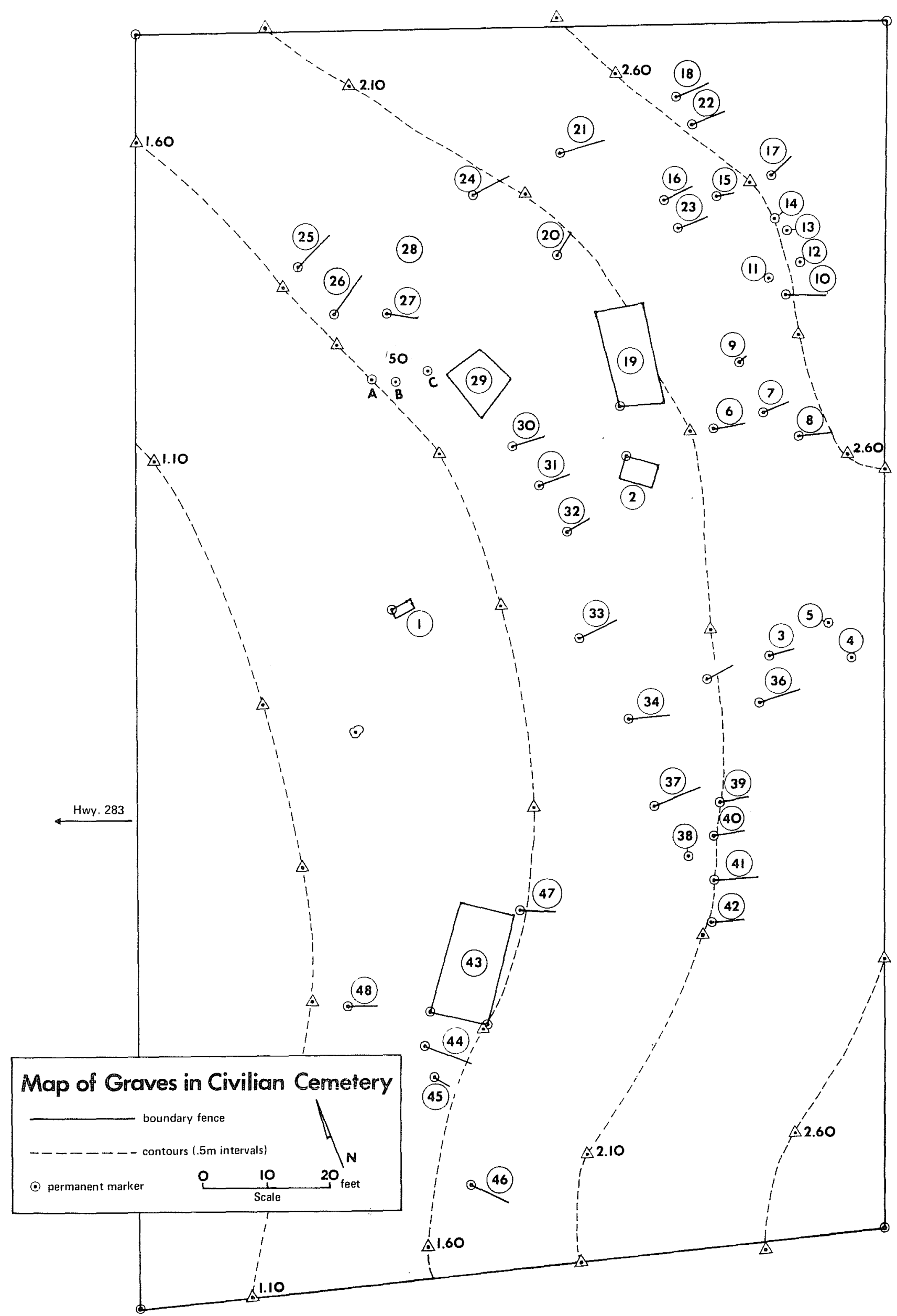




$\begin{array}{cc}\text { In Memory } & \text { G. W. Taylor } \\ \text { of } & \text { Infant Son of } \\ \text { Virgil Hervey } & \text { J. P. \& C. J. } \\ \text { Born Sept. 5th } & \text { Taylor } \\ 1855 & \text { Born } \\ \text { Died June 15th } & \text { Aug. 12, 1883 } \\ 1877 & \text { Died } \\ \text { Aged 21 Years } & \text { Sept. 12, 1883 } \\ 9 \text { Months \& 27 Days } & \end{array}$

A11 data on the markers were recorded. During inclement weather when field work was impossible, a search was conducted in early issues of the Fort Griffin Echo, in the county records, and in numerous books on the history of the town in an attempt to identify those buried in the cemetery and to determine when and by whom it was used. As so often happens, this research turned up information on other cemeteries in the area as we17, a11 of which is included in the Appendix.

An interesting facet of the cemetery investigation was the discovery of a mound marked by a number of rodent burrows. In the back dirt of these creatures were found the following articles (see Fig. 11):

2115 glass beads:

diameter

\begin{tabular}{|c|c|c|}
\hline $\begin{array}{r}2 \\
1728\end{array}$ & $\begin{array}{l}\text { white, olive-shaped, simple construction } \\
\text { white, opaque, donut-shaped, simple }\end{array}$ & $\begin{array}{l}.4 \mathrm{~cm} \\
.125-.2 \mathrm{~cm}\end{array}$ \\
\hline 70 & $\begin{array}{l}\text { construction } \\
\text { turquoise, opaque, donut-shaped, simple } \\
\text { construction. fraqile }\end{array}$ & $.175 \mathrm{~cm}$ \\
\hline 40 & $\begin{array}{l}\text { black, opaque, donut-shaped, simple } \\
\text { construction }\end{array}$ & $.175 \mathrm{~cm}$ \\
\hline 62 & $\begin{array}{l}\text { medium blue, translucent, donut-shaped, } \\
\text { simple construction }\end{array}$ & $.175 \mathrm{~cm}$ \\
\hline 46 & $\begin{array}{l}\text { blue-green, translucent, donut-shaped, } \\
\text { simple construction }\end{array}$ & $.175 \mathrm{~cm}$ \\
\hline 2 & $\begin{array}{l}\text { pale blue, opaque, donut-shaped, simple } \\
\text { construction }\end{array}$ & $.175 \mathrm{~cm}$ \\
\hline 165 & $\begin{array}{l}\text { b7ue, translucent, donut-shaped, simple } \\
\text { construction }\end{array}$ & $.125 \mathrm{~cm}$ \\
\hline $\begin{array}{l}\text { shet } \\
\text { hawk } \\
\text { sphe } \\
\text { squa } \\
\text { wood }\end{array}$ & $\begin{array}{l}\text { hairpipes with traces of vermilion paint } \\
\text { bells } \\
\text { ical brass button } \\
\text { e coffin nails } \\
\text { screws }\end{array}$ & \\
\hline
\end{tabular}

The number, size, and assortment of beads and the presence of the be17s and button suggest a late 19th century Indian garment, such as leggings or a shirt. It would be next to impossible to say for sure what tribe is represented, without seeing the design of the 
Figure 11. Artifacts from Burial 50.

a, hawk bel1

b, donut-shaped beads, .125 to $.175 \mathrm{~cm}$ diameter

c, white, olive-shaped bead, $.4 \mathrm{~cm}$ diameter

d, spherical brass button

e, square coffin nail

$f$,g shell hairpipes with traces of vermilion paint 

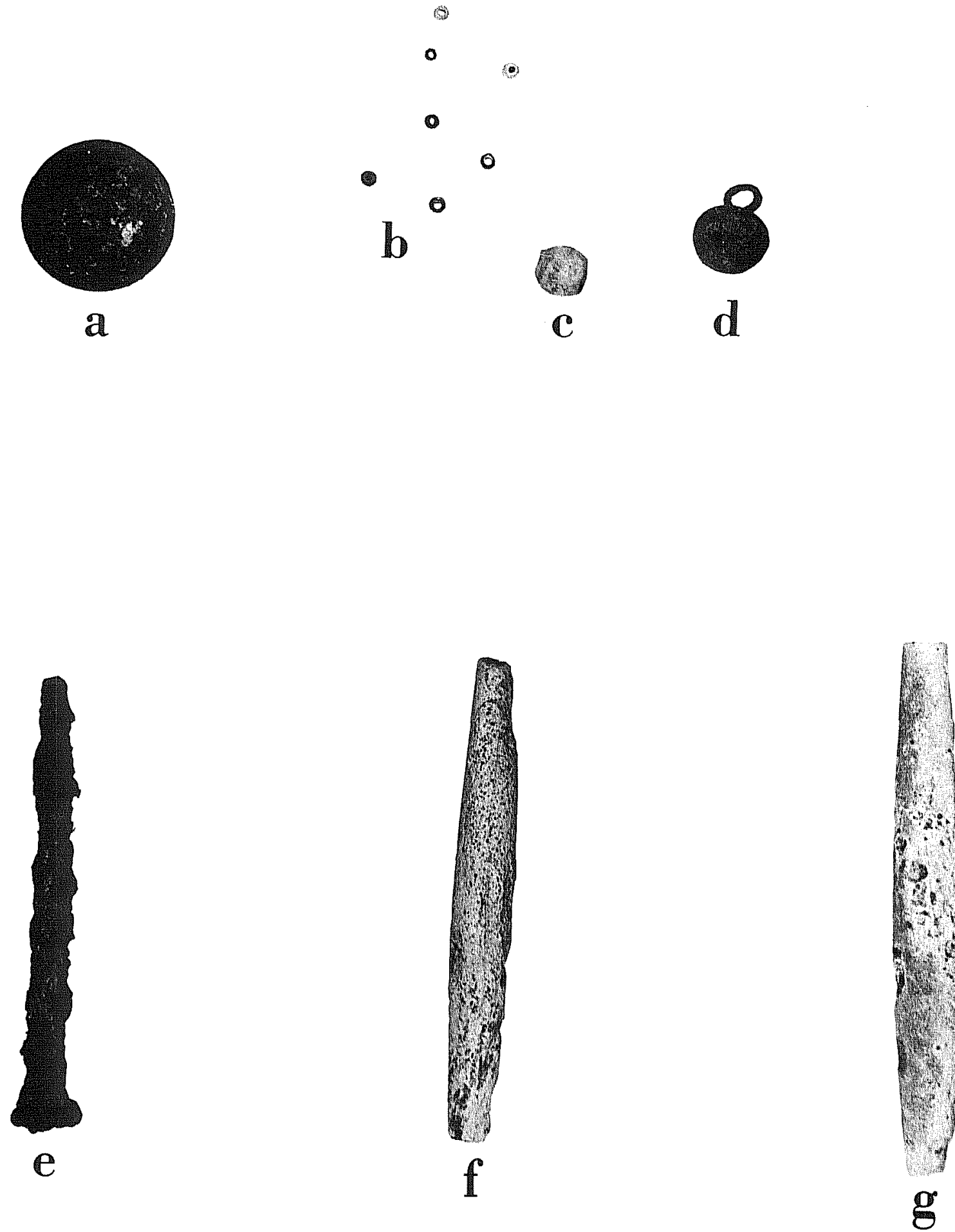

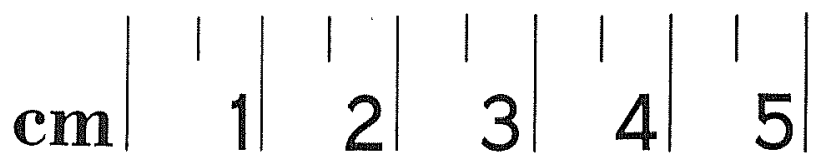


beadwork and the cut of the garment. There is no certainty that even this would help, since by the late $1800^{\prime}$ s beaded garments on the southern plains were heavily influenced by those of the northern plains and frequently were traded among tribes (Word and Fox 1975:57).

The hairpipes could have been part of a breastplate or ear dangles such as were popular among the Kiowa and Comanche in pre-reservation times (Ewers 1957:76). They could also have been suspended on the fringes of a ceremonial shirt, which custom was prevalent among the western Apache (Fox, personal observation in Witte Museum collections).

There are numerous possible explanations for this burial: an Indian far from his home and tribe, a trapper or trader who preferred Indian dress, the Indian wife of a local man. It does not seem likely that it was a Tonkawa scout, as Indian scouts were usually buried in military cemeteries (Neighbors 1973:101; Dr. John Wilson, personal communication).

The small amount of information gathered so far about this cemetery suggests that it was associated with the town of Fort Griffin, and may have been the local "Boot Hill". Rye referred to "Bootleg Hill" when he described a cowboy being buried there (1967:105). Apparently there was another town cemetery in use at the same time, perhaps reserved for the upper class, or more affluent citizens (see Appendix). The known history of Fort Griffin suggests a great need for a cemetery for transients, gunfighters, and riff-raff of the community. For a number of years it was a wide-open, rip-roaring town, rightfully dubbed the "Sodom of the plains" (Metz 1966:48). Rister in his description of the town states (1956:146):

"Within a period of twelve years, thirty-five men had been 'publicly killed', eight or ten others found dead and officers of the law and the vigilantes had shot or strung up twelve more."

\section{THE ARTIFACTS}

The majority of the artifacts recovered during the 1976 investigations were undistinguished fragments of glass bottles and window panes, sherds of heavy, white "ironstone" china, rusted nails, and tin can fragments. The more interesting or meaningful objects have been selected for illustration and identification in the following section.

AREA A - Pathway Trench A76

14 fragments window glass

12 fragments glass containers

1 fragment thin, rusted metal

1 center fire cartridge case (Fig. 12d)

1 trunk key (Fig. 12g)

1 unidentified iron ring

1 plain metal button, 4 holes (Fig. 12c)

1 unidentified metal object (Fig. 12a)

1 iron swivel (Fig. 12h)

14 square nails 
Kitchen-Mess Building 61 , Surface

6 sherds white "ironstone"

77 fragments window glass

11 fragments glass containers

7 piece $3 / 4^{\prime \prime}$ metal strapping

1 piece 1 " metal strapping

1 piece unidentified metal

1 fragment cast iron

18 square nails and fragments

Kitchen-Mess Building G1 Test Trench

8 sherds white "ironstone"

46 fragments window glass

45 fragments glass containers

6 fragments tin cans

1 fragment cast iron kettle (Fig. 13e)

2 fragments bar iron, cut

1 brass insignia number "4" (Fig. 12b)

12 " wood screw

76 square nails and fragments

2 horseshoe nails

8 fragments animal bone

Kitchen-Mess Building $G 1$ South Side of Chimney

13 sherds white "ironstone"

84 fragments window glass

25 fragments glass containers (Fig. $15 \mathrm{c}$ and $\mathrm{f}$ )

34 square nails and fragments

12 " wood screw

3 fragments thin rusted meta 1

1 broken dril1 bit

- 1.22 calibre cartridge

1.9 fragments animal bone

Kitchen-Mess Building 61 North Side of Chimney

2 sherds white "ironstone"

9 fragments window glass

2 fragments glass containers

23 square nails and fragments

2 horseshoe nails

$111 / 4$ " screw

1 complete horseshoe

2 fragments unidentified iron object

1 metal tubing with threaded end (Fig. 12i)

1 fragment mussel shel1

36 fragments animal bone 
Kitchen-Mess Building G4 Chimney Surface to Sterile Soil

63 fragments window glass

225 fragments glass containers (Fig. 15a,b,e,g)

1 fragment heavy meta 7 bar, $11 / 2^{\prime \prime} \times 197 / 2^{\prime \prime}$

12 fragments tin cans

1 fragment 5/8" wide metal strapping

2 heavy wire hooks (Fig. 12j.)

2 fragments unidentified cast iron object

1 fragment iron hinge (Fig. 12k)

1 fragment copper/brass tubing

3 fragments rusted metal

69 square nails and fragments

1 large square spike, $5^{\text {" }}$ long

1 bag mortar samples

18 fragments animal bone

Kitchen-Mess Building G4 Chimney Surface

3 fragments window glass

20 fragments glass container

4 fragments cast iron

1 fragment thin rusted metal

3 square nails and fragments

AREA B - K2 Barracks

5 fragments window glass

5 fragments glass containers

2 fragments unidentified metal object

1 fragment thin rusted metal

20 square nails

1 large square spike

AREA C - Pathway Trench B76

1 sherd white "ironstone"

5 sherds crockery (Fig. 13b,c)

2 fragments window glass

7 fragments glass container

.1 fragment heavy iron strap, $11 / 4^{\prime \prime} \times 31 / 2^{\prime \prime}$

1 fragment iron hook (?)

2 wire nails

1 square nail

3 fragments animal bone

Pathway Trench $\mathrm{C76}$

3 fragments thin rusted metal

1 fence staple

1 Targe piece of wire

1 fragment thin metal strap with attachment

1 square nait

10 fragments glass container (Fig. 15d) 
Pathway Trench 076

I square nail

Pathway Clearing E76

16 sherds white "ironstone" (Fig. 13a)

3 sherds crockery

1 fragment glass container

2 tin cans (Fig. 13d)

1 fragment lock plate

1 square nail

AREA D - Fence Post

1 fragment glass container

7 fence staples

3 fragments barbed wire

Trench I

2 fragments glass containers

1 fragment thin rusted meta 1

1 square nail

Trench II

3 fragments glass containers

1 flattened artillery primer

1 Targe square spike

Trench III

1 fragment glass container

3 brass artillery primers (Fig. 12f)

6 fragments twisted brass wire (Fig. 12e)

4 square nails

F Blacksmith Shop (see Fig. 14)

2 sherds white "ironstone"

31 fragments glass containers

3 fragments window glass

11 fragments thin rusted meta 1

1 fragment thin, unidentified metal

1 brass grommet

1 plain, 4-hole metal button

1 brass uniform button

1 fragment artillery primer

2 wire nails

97 square nails and fragments

2 heavy, square spikes

145 chunks iron 


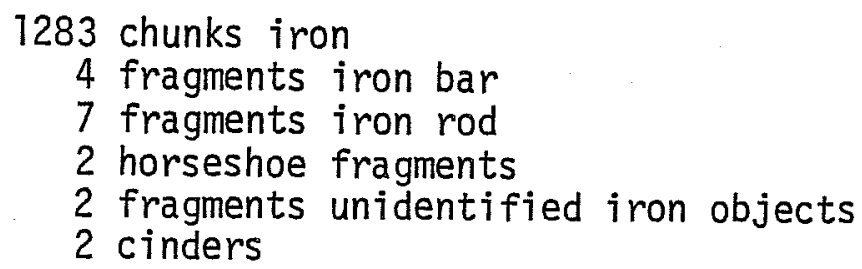

\section{CONCLUSIONS AND RECOMMENDATIONS}

During the spring of 1976, an archaeological crew relocated pathways and buildings and marked them with permanent metal stakes, investigated locations to determine whether pathways or structures had existed there, and in general tied up loose ends in an overall assessment of the fort begun in 1973. As a result of two seasons' work at Fort Griffin, the senior author has reached a number of conclusions concerning archaeology at Fort Griffin.

Due to constant wind deflation on the hilltop, the archaeology of the fort is very fragile, with little or no deposition to protect historic deposits. Extreme care should be taken at all times to preserve the grass cover and avoid further erosion, particularly in areas around structures which have never been investigated. Artifactual and structural evidence, while quite thin and sometimes difficult to "read", is nevertheless still present over most of the area.

Chimney bases which were uncovered during the 1973 and 1976 seasons badly need stabilization. This should be done as soon as possible, since evidence was found this time that chimneys mapped in 1973 are deteriorating rapidly despite the sand backfilling done at the end of that season.

The restoration of pathways around the barracks huts and kitchen-mess buildings would aid greatly in interpretation of the fort for the visitor. It is suggested that these paths stop short of the kitchenmess buildings, at the north-south pathway across the ends of the hut rows, avoiding the rather delicate archaeological zone around the buildings. Explanatory signs and restoration of chimney bases would probably suffice to explain the area without disturbing the ground.

It does not seem a good idea to construct pathways around the officers' quarters in Area $C$ at this time. There are a number of rather deep cellar holes and latrine pits in the area which could prove hazardous to the adventurous visitor, and, here again, the archaeological evidence should not be disturbed. 
Figure 12. Metal Artifacts

a, unidentified metal object

b, military insignia, lead-backed, probabiy 4th Cavairy, at Fort Griffin 1874 to 1875 (Rodenbaugh and Haskin 1966:217).

c, metal button

d, center fire cartridge case from Colt 45 revolver, externally primed, no head stamp.

e, brass wire with serrated end, part of artillery friction primer.

$f$, copper tube, part of artillery friction primer

g, trunk or furniture key

$h$, iron swivel

$i$, lead or zinc tubing with threaded end

$j$, wire hook

$k$, hinge fragment
Provenience

Area A, pathway trench A76

Area $A$, kitchen-mess building G1 trench

Area A, pathway trench A76

Area A, pathway trench A76

Area D, Trench III

Area D, Trench III

Area A, pathway trench A76

Area A, pathway trench A76

Area $A$, chimney of $G 1$

Area $A$, chimney of $G 4$

Area A, chimney of G4 

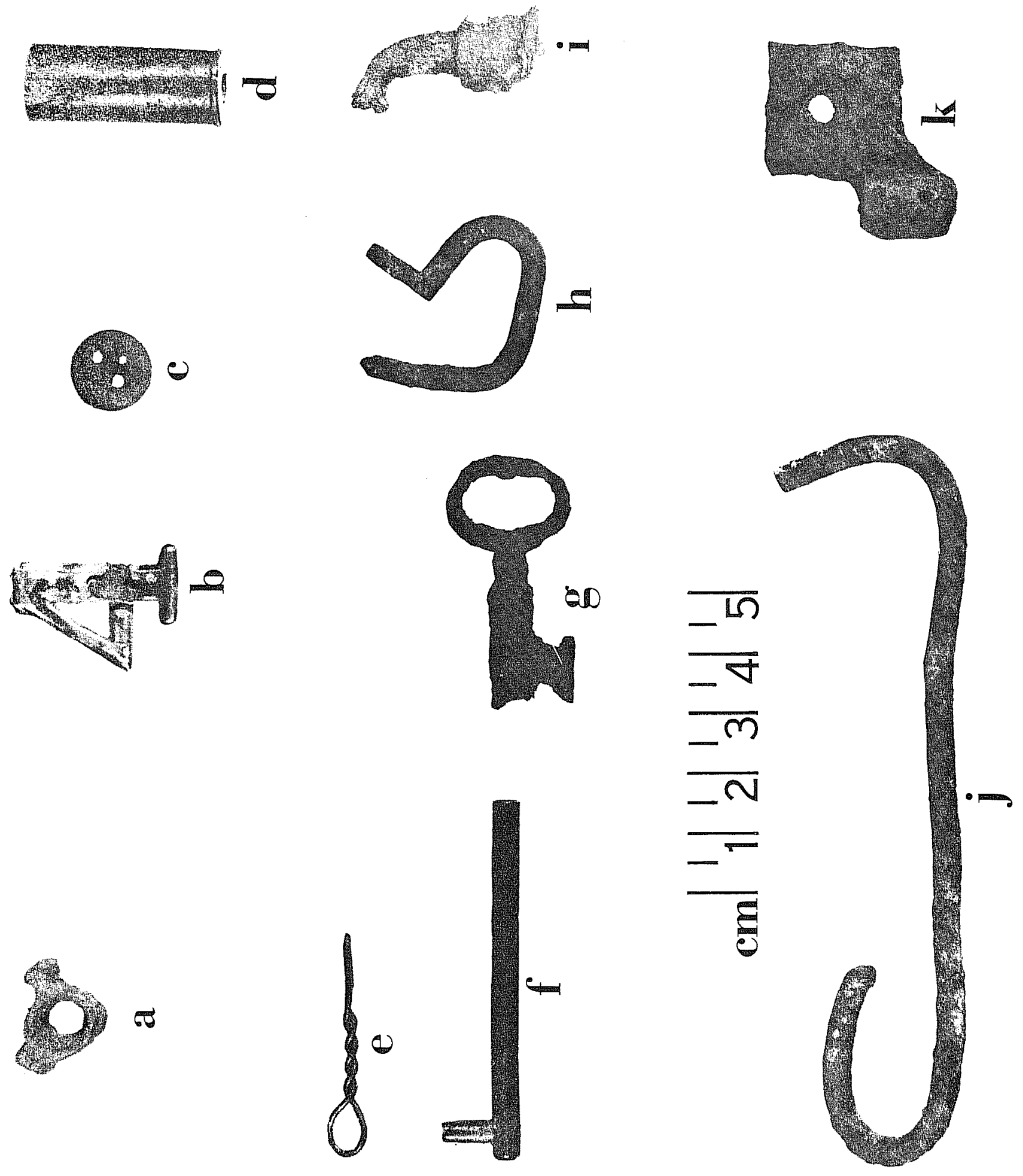
Figure 13. Domestic Articles

a, white ironstone rim

b, fragment of stoneware crock lid

c, fragment of stoneware crock

d, tin can with soldered seams

e, cast iron kettle fragment

Provenience

Area C, trench E76

Area $C$, trench E76

Area $C$, trench B76

Area $C$, trench E76

Area $A$, trench $\mathrm{GT}$ 

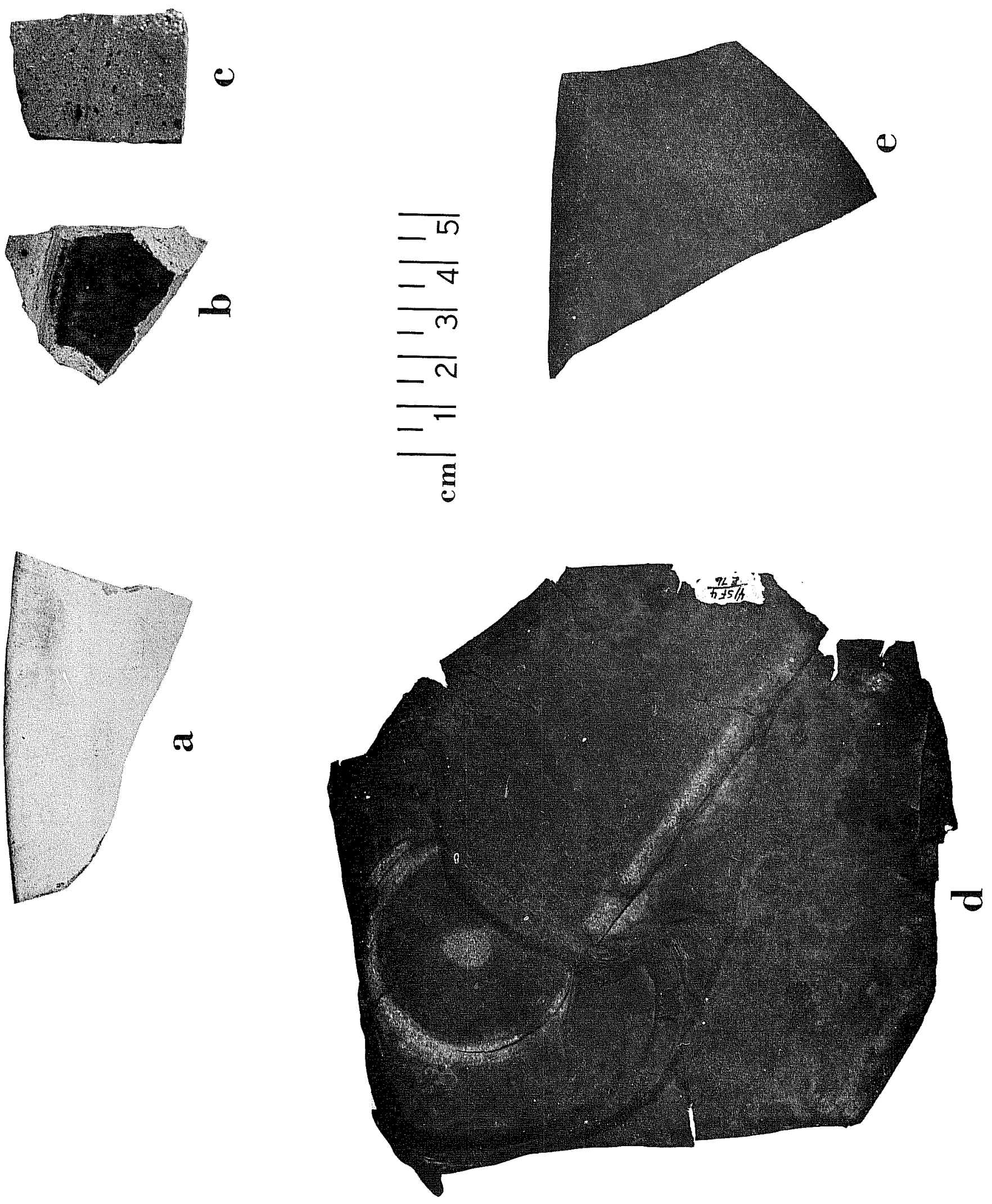
Figure 14. Artifacts from Blacksmith Shop. F2

a, worn horseshoe fragment

$b$, heavy spike

c,d square nails

e, brass military button, marked "Waterbury Button Co."

$f$, horseshoe nail

$g, h$ iron bar chunks

$i$, iron rod fragment

$j$, iron hardware fragment

$k$, heavy iron bar 

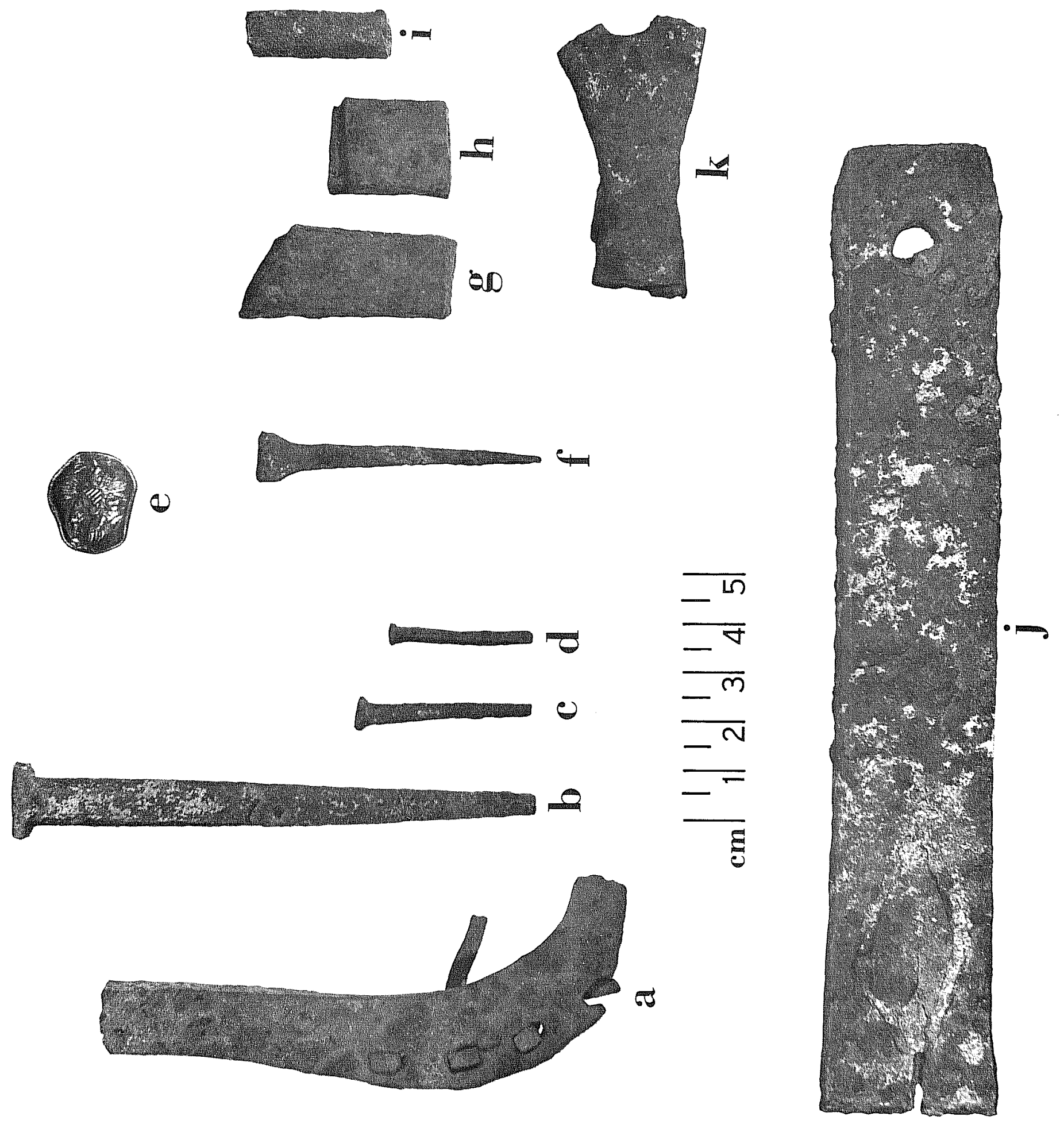
Figure 15. Glass Bottles
a, aqua rim fragment
G4 chimney
$b$, clear glass neck
G4 chimney
c, blue-green rim fragment
G1 chimney
d, dark green neck with sheared lip
Trench C76
e, aqua screw-top jar
$f$, clear panel bottle
G4 chimney
GI chimney
g, dark green wine bottle with kickup
G4 chimney 

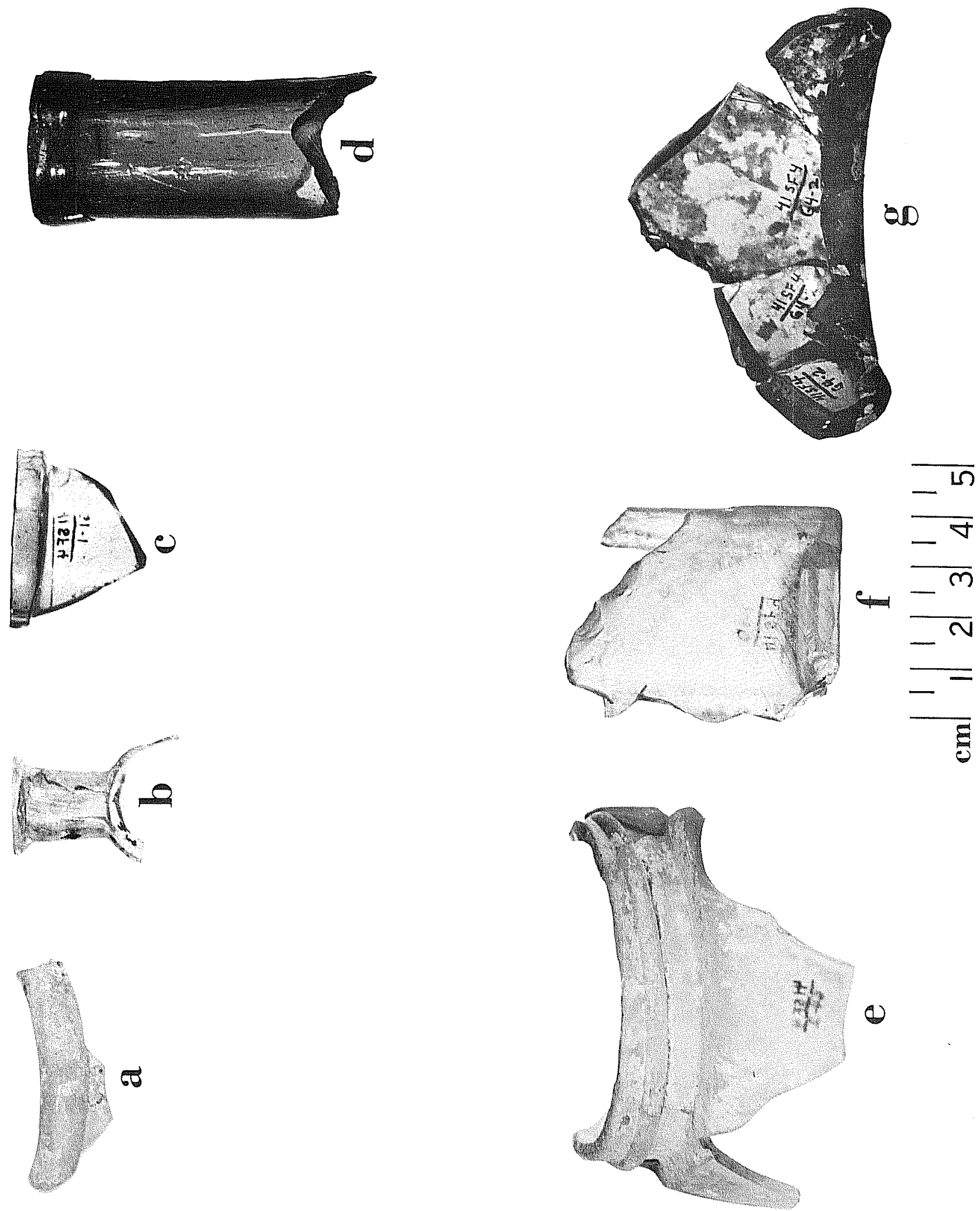


\section{APPENDIX}

\section{Cemeteries in the Fort Griffin Area}

The following information about the cemeteries in the vicinity of Fort Griffin was collected by the archaeological crew. It is included here for possible use in future interpretative plans for the park.

No information was found about J. P. and C. J. Taylor, although a number of Taylors lived in the towns of Fort Griffin and Albany during the 1880's. The Herveys, however, were an entirely different matter.

Through newspaper accounts and popular local stories, it was possible to determine that there were two Herveys, probab7y brothers and probably both ex-circus performers. Rye $(1967: 78)$ says that Julius or Jules had been an acrobat, and such acts have traditionally been family affairs. They must have arrived in town early in 1877, for in the spring of that year, J. F. and V. J. Hervey bought and sold 7 and in Fort Griffin (Deed Records, Vol. C pp. 246-250, Shackelford County Court House). In June of that year Virgil was killed by A. L. "Long John" Mont (Echo, May 10, 1879). In 1878 Julius had a restaurant in town (Rister 1956:195). Evidently at some point in his career he worked as a barkeep in a local saloon, as an updated story relates his role in subduing a drunken bully with a lasso (Rye 1967:77-82). In the spring of 1881 Hervey sold his restaurant (Echo, Apri1 9, 1881), bought a span of horses, a wagon, and a pair of mules declaring he had the "railroad fever" (Echo, March 5, 1881). After incurring a fine of $\$ 14.50$ for "rudely displaying a pistol in a public place," he and his family went to Beard City on March 10th (Echo, March 12, 1881).

As a postscript, we might add that Jules' wife and a Mrs. Walsh opened a new restaurant in Fort Griffin the following year (Echo, January 14, 1882). No record was found of what happened to Jules. Local historian Joan Farmer reports he was killed by a buffalo. He may occupy one of the graves adjacent to Virgil's in the cemetery on Highway 283 . No information was found concerning "Little Lulu." Since no surviving widow was mentioned in the newspaper account of Virgil's death, it seems likely that she was Jules' child.

Other cemeteries in the immediate Fort Griffin area included the military cemetery in the fort, from which the burials were supposedly removed to San Antonio when Highway 283 was built; one on a hill over the T. P. Fincher place, several miles upstream on the west bank of the Clear Fork; and one known as the Negro cemetery on a ridge approximately a mile west of the old town site, which contains about 12 graves (Nash 1975:70).

The cemetery near the Fincher place contains over 25 graves, some unmarked except for a rough headstone, but most with elaborate stones dating from 1878 to 1900 , with one dated 1949. These include several names of families prominent both in Fort Griffin history and in that of Albany, where most of the old town's inhabitants eventually moved. Apparent7y this cemetery was in use at the same time as the one mapped by the archaeologists on Highway 283. It would be interesting to know how the decision was made as to where a particular person should be buried. Segregation of burials according to race, religion, and social 
status is still practiced in some areas of the country.

Another cemetery in the area is the one near Camp Cooper described by Biggers:

"A short distance west of the old post site is Graveyard Canyon, a deep, dark, dismal and rough enough place, which derives its name from a most natural circumstance, a graveyard just at the foot of a mountain forming one of its confines. This graveyard belongs to the reservation and not a person has been buried there since the beginning of the Civil War. Only white persons are buried there, and each grave is that of a soldier or person connected with the service or some member of such person's famity. There are eighteen of these graves, possibly more. Four of these are of children and there is absolutely no means by which to ascertain who is buried there or when the occupant of the grave died..... Around most of the graves is a stone vault covered with one or two large, flat rocks from the mountainside nearby. But most of the graves not so protected are easily protected by a mound." (Biggers 1974:64)

Evidently the custom of building a stone vault around and over a grave was popular in pre-Civil War times and was continued by a few families into the late 1800 's. However, no structures of this type were observed in the Albany cemetery, which has been in use since about 1900 , possibly indicating the end of the practice at about this time. 


\section{BIBLIOGRAPHY}

Beard, Roland

n.d. Excavation notes on file at Texas Parks and Wildlife Department, Austin.

Biggers, Don $\mathrm{H}$.

1974 Shackelford County Sketches. Edited and annotated by Joan Farmer. The Clear Fork Press, Albany and Fort Griffin.

Ewers, John C.

1957 Hair Pipes in Plains Indian Adornment. Bureau of American Ethnology Bulletin 164: 29-85.

Fort Griffin Echo

$$
\begin{aligned}
& \text { May 10, } 1879 \\
& \text { March } 5,1881 \\
& \text { March 12, } 1881 \\
& \text { Apri1 9, } 1881 \\
& \text { January } 14,1882
\end{aligned}
$$

Fox, Anne A.

1973 Archeological Investigations at Fort Griffin State Historic Park, Texas, February, 1973. Texas Archeological Survey Research Report 21.

Graham, Roy E.

1968 Texas Historic Forts, Park IV, Griffin. Texas Parks and Wild 7 ife Department, Austin.

Matthews, Sallie Reynolds

1958 Interwoven, A Pioneer Chronicle. Hertzog, E1 Paso.

Metz, Leon Claire

1966 John Selman, Texas Gunfighter. Hastings House, New York. Nash, Sharon

1975 Countryside Graveyard. Old Timer I: 70-71.

National Archives, Record Group 92

1869 Report of al1 buildings at Fort Griffin, Texas, for the month of June, 1869. 
1873 "Inspection Report", John P. Hatch, Lt.Col. 5th Cavalry, Special Inspector.

1875 Report showing the character and condition of Public Buildings at Fort Griffin, Texas, June 21st, 1875.

1879 Report showing character and condition of buildings at Fort Griffin, Texas, June 30, 1879.

Neighbors, Kenneth F.

1973 Tonkawa Scouts and Guides. West Texas Historical

Association Yearbook XLIX: 90-113.

01ds, Dorris L.

1969 Archeological Investigation at Fort Griffin Military Post, Shackelford County, Texas. Texas Archeological Research Laboratory, Austin.

Rister, Carl Coke

1956 Fort Griffin on the Texas Frontier. University of OkTahoma Press, Norman.

Rodenbough, Theodore F. and William L. Haskin, editors

1966 The Army of the United States. Argonaut Press Ltd., New York.

Rye, Edgar

1967 The Quirt and the Spur. Steck-Vaughn Company, Austin. Word, James H. and Anne A. Fox

1975 The Cogde11 Burial in Floyd County, Texas. Bulletin of the Texas Archeological Society 46: 1-64. 